\title{
Urological complications after radiation therapy-nothing ventured, nothing gained: a Narrative Review
}

\author{
Joanna Chorbińska^, Wojciech Krajewski^, Romuald Zdrojowy^ \\ Department of Urology and Oncologic Urology, Wroclaw Medical University, Wrocław, Poland \\ Contributions: (I) Conception and design: W Krajewski, J Chorbińska; (II) Administrative support: R Zdrojowy; (III) Provision of study materials \\ or patients: R Zdrojowy; (IV) Collection and assembly of data: J Chorbińska, W Krajewski; (V) Data analysis and interpretation: J Chorbińska, W \\ Krajewski; (VI) Manuscript writing: All authors; (VII) Final approval of manuscript: All authors. \\ Correspondence to: Joanna Chorbińska. Department of Urology and Oncologic Urology, Wroclaw Medical University, ul. Borowska 213, 50-556 \\ Wrocław, Poland. Email: achorbik@gmail.com.
}

\begin{abstract}
Radiation therapy along with chemotherapy and surgery are the three main treatment modalities used in oncology. The main disadvantage of radiotherapy is the fact that it affects both cancer and healthy cells located in the tumour area. As a consequence, different complications develop. A large proportion of cancers treated with radiotherapy are located in the lower abdomen and pelvis, which is why complications often involve the urinary tract. Due to the anatomy of these areas, urological complications occur not only after radiological treatment of urological cancers, but also after treatment of malignancies of the reproductive or digestive system. The most common radiation-induced complications include haemorrhagic cystitis, urethral and ureteral strictures, urinary fistulae, and secondary primary malignancies. Adverse events significantly degrade the quality of life of the patient, and in severe cases can be life threatening to the patient. Because of impaired tissue healing, the treatment of radiation urological complications is a challenge for urologists and often requires complicated reconstruction techniques. Continuous increase in the effectiveness of cancer treatments and the extension of patients' lives, make complications of radiation therapy an increasingly common clinical problem. The aim of this review is to present the pathophysiology, clinical presentation and methods of treatment for radiation-induced urological complications.
\end{abstract}

Keywords: Radiotherapy; urological complications; pelvic malignancy; radiation cystitis

Submitted Jul 24, 2020. Accepted for publication Nov 20, 2020.

doi: $10.21037 /$ tcr-20-2589

View this article at: http://dx.doi.org/10.21037/tcr-20-2589

\section{Introduction}

Radiation therapy along with chemotherapy and surgery are the three main treatment modalities used in oncology $(1,2)$. It is estimated that approximately $50 \%$ of patients will receive radiotherapy during the cancer treatment (1-4). It is the most-effective cytotoxic therapy available for the treatment of localized solid malignancies (5-7).

The main disadvantage of radiation therapy is the fact that it affects both cancer and healthy cells located in the tumour area. Although advances in radiotherapy, such as intensity-modulated radiotherapy (IMRT), conformal radiotherapy (CRT), and high-energy linear accelerators have enabled more accurate delivery of radiation to the tumour and the limitation of surrounding tissue exposition, the effects of this type of therapy on healthy tissues have not been completely eliminated (2,5,7-12). An additional way to reduce complications is the use of so-called radioprotectors.

^ ORCID: Joanna Chorbińska, 0000-0001-9792-4450; Wojciech Krajewski, 0000-0003-1727-2283; Romuald Zdrojowy, 0000-0002-16343556. 
These are agents administered prior to or during irradiation to prevent or reduce damage to normal tissue. To date, amifostine is the only clinically used radioprotector, but it can cause various side effects, including hypotension. The use of other compounds in the protection of normal tissues, e.g., melatonin, metformin, nitroxides, shows promising results in preclinical studies $(13,14)$.

The degree of damage to healthy tissues, depends on tissues' radiosensitivity, the size of radiation doses and the irradiated area, the intervals between doses, the method of delivery and the patient's factors such as comorbidities $(2,7,11,12)$. Some of these factors are modifiable, allowing the protection of normal tissues against damage. An example is hyperfractionation, which is the administration of a high total dose of radiation distributed over a large number of small doses per fraction. Normal tissues are more sensitive to fraction size changes than tumours, and with smaller doses per fraction, normal tissues can repair radiation damage more effectively than cancer cells (12).

Complications related to radiotherapy can be divided into acute and late. Acute ones may occur during treatment or within days or weeks after irradiation, while late ones may appear after a few months or even years. Some authors consider 90 days as the threshold between acute and late complications $(7,9,10,14-17)$.

A large proportion of cancers treated with radiotherapy are located in the lower abdomen and pelvis, which is why complications often involve the urinary tract. Due to the anatomy of these areas, urological complications occur after radiological treatment of malignancies of genitourinary and digestive system. The most common pelvic cancers requiring radiotherapy include prostate cancer, rectal cancer and anal cancer in men, and cervical cancer and vulvar cancer in women. Other tumours that cause urological complications after radiation include bladder cancer, ovarian cancer, urethral cancer, endometrial cancer, testicular cancer, and vaginal cancer $(7,12,16,18-22)$.

The aim of this study is to analyse the literature on urological complications after radiotherapy for various cancers, their pathophysiology, clinical presentation and methods of treatment. We present the following article in accordance with the narrative review reporting checklist (available at http://dx.doi.org/10.21037/tcr-20-2589).

\section{Evidence acquisition}

A narrative review was carried out due to the low quality of the evidence available. A literature search was performed using the PubMed and Google Scholar electronic databases. The search was limited to English and German articles published until July 2020. Searched terms included: "urological complications", "pelvic radiotherapy", "radiation cystitis", "fistula", "ureteral stricture", "urethral stricture", "second primary cancer", along with free-text, related, derivative, and exploded terms.

\section{Types of complications}

Damage caused by radiation therapy most often affects the bladder and ureters $(16,23,24)$. The most common radiation complications include haemorrhagic cystitis, urethral and ureteral strictures, urinary fistulae, and secondary primary malignancies $(7,10,18,19,21)$. Less common are erectile dysfunction, infertility, lower urinary tract dysfunction, bladder fibrosis and necrosis. As a result, chronic kidney disease may develop $(7,9,18,21)$. Radiation-induced urological complications were first reported in 1927 by Dean. He described ulceration of the urinary bladder following the use of radium in a patient with uterine cancer (25).

\section{Grading}

Several scales were proposed to assess the severity of acute and late radiological toxicity. The two most commonly used in clinical practice are Radiation Therapy Oncology Group (RTOG)/European Organization for Research and Treatment of Cancer (EORTC) and National Cancer Institute Common Terminology Criteria for Adverse Events (NCI CTCAE) (Table 1) (26,27). Another scale is LENT-SOMA, which occurs in a separate version for each organ or tissue that may be in the irradiation field. It includes 4 elements, representing the subjective, objective, management and analytical (SOMA) assessment of late effects on normal tissues (LENT). Although comprehensive, it is mainly used in clinical studies $(28,29)$.

\section{Epidemiology}

Urological complications after radiotherapy are usually mild and moderate (RTOG grades 1-2) (22,30). Severe (RTOG grades 3-4) occur most frequently after treatment of cervical cancer, prostate cancer and bladder cancer $(16,22)$. The most common late adverse event is radiation cystitis, which occurs in $5-10 \%$ of patients undergoing pelvic radiotherapy $(16,21,23,24,31,32)$. The frequency of a given complication depends on the type of cancer. Radiation cystitis occurs 
Table 1 Genitourinary complications according to the Radiation Therapy Oncology Group (RTOG)/European Organisation for Research and Treatment of Cancer (EORTC) morbidity scale and the Common Terminology Criteria for Adverse Events (CTCAE) v5.0

\begin{tabular}{|c|c|c|c|c|c|}
\hline Organ/complication & Grade 1 & Grade 2 & Grade 3 & Grade 4 & Grade 5 \\
\hline $\begin{array}{l}\text { Genitourinary/ } \\
\text { bladder acute }\end{array}$ & $\begin{array}{l}\text { Frequency of } \\
\text { urination or } \\
\text { nocturia twice } \\
\text { pretreatment habit/ } \\
\text { dysuria, urgency } \\
\text { not requiring } \\
\text { medication }\end{array}$ & $\begin{array}{l}\text { Frequency of urination } \\
\text { or nocturia that is less } \\
\text { frequent than every } \\
\text { hour. Dysuria, urgency, } \\
\text { bladder spasm requiring } \\
\text { local anaesthetic (e.g., } \\
\text { Pyridium) }\end{array}$ & $\begin{array}{l}\text { Frequency with urgency } \\
\text { and nocturia hourly or more } \\
\text { frequently/dysuria, pelvis } \\
\text { pain or bladder spasm } \\
\text { requiring regular, frequent } \\
\text { narcotic/gross haematuria } \\
\text { with/without clot passage }\end{array}$ & $\begin{array}{l}\text { Haematuria } \\
\text { requiring } \\
\text { transfusion/acute } \\
\text { bladder obstruction } \\
\text { not secondary } \\
\text { to clot passage, } \\
\text { ulceration, or } \\
\text { necrosis }\end{array}$ & Death \\
\hline $\begin{array}{l}\text { Genitourinary/ } \\
\text { bladder late }\end{array}$ & $\begin{array}{l}\text { Slight epithelial } \\
\text { atrophy; minor } \\
\text { telangiectasia } \\
\text { (microscopic } \\
\text { haematuria) }\end{array}$ & $\begin{array}{l}\text { Moderate frequency; } \\
\text { generalized } \\
\text { telangiectasia; } \\
\text { intermittent macroscopic } \\
\text { haematuria }\end{array}$ & $\begin{array}{l}\text { Severe frequency and } \\
\text { dysuria; severe telangiectasia } \\
\text { (often with petechiae). } \\
\text { Frequent haematuria; } \\
\text { reduction in bladder capacity } \\
\text { (<150 cc) }\end{array}$ & $\begin{array}{l}\text { Necrosis/ } \\
\text { Contracted } \\
\text { bladder (capacity } \\
<100 \mathrm{cc} \text { ). Severe } \\
\text { haemorrhagic } \\
\text { cystitis }\end{array}$ & Death \\
\hline \multicolumn{6}{|c|}{ Common Terminology Criteria for Adverse Events (CTCAE) v5.0 } \\
\hline Haematuria & $\begin{array}{l}\text { Asymptomatic; } \\
\text { clinical or } \\
\text { diagnostic } \\
\text { observations only; } \\
\text { intervention not } \\
\text { indicated }\end{array}$ & $\begin{array}{l}\text { Symptomatic; urinary } \\
\text { catheter or bladder } \\
\text { irrigation indicated; } \\
\text { limiting instrumental ADL }\end{array}$ & $\begin{array}{l}\text { Gross haematuria; } \\
\text { transfusion, IV medications, } \\
\text { or hospitalization indicated; } \\
\text { elective invasive intervention } \\
\text { indicated; limiting self-care } \\
\text { ADL }\end{array}$ & $\begin{array}{l}\text { Life-threatening } \\
\text { consequences; } \\
\text { urgent invasive } \\
\text { intervention } \\
\text { indicated }\end{array}$ & Death \\
\hline $\begin{array}{l}\text { Cystitis } \\
\text { noninfective }\end{array}$ & $\begin{array}{l}\text { Microscopic } \\
\text { haematuria; } \\
\text { minimal increase } \\
\text { in frequency, } \\
\text { urgency, dysuria, or } \\
\text { nocturia; new onset } \\
\text { of incontinence }\end{array}$ & $\begin{array}{l}\text { Moderate haematuria; } \\
\text { moderate increase in } \\
\text { frequency, urgency, } \\
\text { dysuria, nocturia or } \\
\text { incontinence; urinary } \\
\text { catheter placement } \\
\text { or bladder irrigation } \\
\text { indicated; limiting } \\
\text { instrumental ADL }\end{array}$ & $\begin{array}{l}\text { Gross haematuria; } \\
\text { transfusion, IV medications, } \\
\text { or hospitalization indicated; } \\
\text { elective invasive intervention } \\
\text { indicated }\end{array}$ & $\begin{array}{l}\text { Life-threatening } \\
\text { consequences; } \\
\text { urgent invasive } \\
\text { intervention } \\
\text { indicated }\end{array}$ & Death \\
\hline Urinary fistula & - & $\begin{array}{l}\text { Symptomatic, invasive } \\
\text { intervention not indicated }\end{array}$ & $\begin{array}{l}\text { Invasive intervention } \\
\text { indicated }\end{array}$ & $\begin{array}{l}\text { Life-threatening } \\
\text { consequences; } \\
\text { urgent invasive } \\
\text { intervention } \\
\text { indicated }\end{array}$ & Death \\
\hline $\begin{array}{l}\text { Urinary tract } \\
\text { obstruction }\end{array}$ & $\begin{array}{l}\text { Asymptomatic; } \\
\text { clinical or } \\
\text { diagnostic } \\
\text { observations only; } \\
\text { intervention not } \\
\text { indicated }\end{array}$ & $\begin{array}{l}\text { Symptomatic but no } \\
\text { hydronephrosis, sepsis, } \\
\text { or renal dysfunction; } \\
\text { urethral dilation, urinary } \\
\text { or suprapubic catheter } \\
\text { indicated }\end{array}$ & $\begin{array}{l}\text { Altered organ function } \\
\text { (e.g., hydronephrosis or } \\
\text { renal dysfunction); invasive } \\
\text { intervention indicated }\end{array}$ & $\begin{array}{l}\text { Life-threatening } \\
\text { consequences; } \\
\text { urgent intervention } \\
\text { indicated }\end{array}$ & Death \\
\hline
\end{tabular}

$A D L$, activities of daily living; IV, intravenous. 
most frequently after prostate, bladder and cervical cancer treatment, ureteral stenosis after cervical radiotherapy, and urethral stenosis after brachytherapy of prostate cancer $(6,12,22,33)$. The latency period between the end of treatment and the onset of complications may be up to 30 years, and the risk of developing adverse events increases with time $(22,33,34)$.

The incidence of urological complications depends on the method of treatment for prostate cancer. In the case of external beam radiotherapy, the incidence of adverse events was $20-43 \%, 7-19 \%$ and $5-13 \%$ for RTOG grade 1, 2, 3, respectively, after 10 years. The most common complication is radiation cystitis (35-40). In the case of brachytherapy, the incidence of adverse events was $36 \%, 24 \%, 6.2 \%$ and $0.1 \%$ for RTOG grade 1, 2, 3 and 4, respectively, with followup of up to 5 years. The most common complications of brachytherapy include haematuria, obstructive or irritating urinary tract symptoms and urethral stricture $(41,42)$.

Late urological complications following radiation therapy for bladder cancer were reported in $18-27 \%$ patients for RTOG grade 2 and in 6-17\% patients for RTOG grade 3 or higher, with a median follow-up of 29-76 months (43-46).

After radiation therapy for cervical cancer, late complications occur in 7-9.8\% patients for RTOG 1-2 and in $1.3-14.5 \%$ patients for RTOG $3-4$ after 3 years. The most common adverse events include radiation cystitis, ureteral stenosis and vesicovaginal fistula (47-53).

The incidence of mild to moderate (RTOG grade 1-2) adverse events after radiotherapy for endometrial cancer is $11-17 \%$ (54-57). There were no serious (RTOG grade $3-4)$ complications with a median follow-up of 52 and 68 months, except for one series of cases in which ureteric stenosis was described in $6 \%$ of patients $(54-56,58)$.

Late severe urological complications after irradiation of colorectal cancer occur in $2-4 \%$ of patients (59).

\section{Radiation cystitis}

Radiation cystitis is one of the most common complications of radiation therapy $(19,60)$. It occurs in $5 \%$ to $10 \%$ of patients undergoing pelvic irradiation and most often complicate treatment for prostate, bladder or cervical cancer $(12,21,23,24,31)$. Acute radiation cystitis is common and usually self-limiting $(24,32)$. Chronic haemorrhagic cystitis is a rare, progressive and irreversible condition that can occur up to 20 years after irradiation, and its treatment is a challenge to modern medicine (24,61-63). Both forms of cystitis significantly affect patients' quality of life and can lead to life-threatening situations $(24,30)$. Complications of radiation therapy constitute up to $7 \%$ of emergency admissions to the urology department (19).

\section{Pathophysiology}

Among all the organs of the urinary system, urinary bladder is the most sensitive to radiation $(12,64)$. The exact mechanism of radiation cystitis is unknown, but 3 phases of this process are commonly distinguished: an acute phase, self-limiting, occurring up to 6 weeks after radiation therapy; a latent phase, asymptomatic, dose-dependent, lasting months or years; and a chronic and irreversible late phase (61,64-67).

Acute radiation cystitis is caused by damage to the bladder mucosa and it is characterized by hyperaemia, mucosal oedema and inflammation. The physiological urothelial barrier is impaired, which leads to secondary damage to deeper tissues through contact with urine and the spread of inflammation $(61,65,68)$.

A feature of late damage is obliterative endarteritis $(12,69)$. Tissues become hypovascular, hypocellular and hypoxic (so-called "three-H tissue") $(30,32,70)$. Hypoxia leads to necrosis of the mucosa, which is manifested by bleeding and necrosis of the detrusor muscle, which promotes fistula formation to adjacent organs $(12,68,70,71)$. Ischemia also stimulates progressive fibrosis of the bladder wall, which, when severe, may lead to a decrease in bladder capacity and, as a consequence, to urinary incontinence $(12,65,69)$. Telangiectasia also develops, and the dilated vessels are fragile and can be a source of bleeding and pain $(32,64,65,69-71)$.

\section{Clinical presentation}

Acute radiation cystitis occurs during or shortly after irradiation. It manifests as dysuria and increased frequency and urgency to urinate. It is characterized by self-limiting course and usually lasts up to 3 months (32).

The main symptom of chronic radiation cystitis is haematuria of varying severity-from mild haematuria to severe life-threatening haemorrhage leading to hypovolemic shock $(32,64,72,73)$. Haematuria with clot formation may cause urinary retention $(32,64)$. Other ailments include lower urinary tract symptoms such as nocturia, urgency, dysuria, frequency and urinary incontinence. In addition, patients may complain of suprapubic pain and fatigue $(21,31,62,64-69,72,74)$. 
Among the risk factors for chronic radiation cystitis, in addition to the previously mentioned radiationrelated factors, are the comorbidities e.g., diabetes and hypertension, previous unrelated abdominal surgery, stage of the cancer, as well as other cancer treatment methods such as chemotherapy or surgery along with postoperative complications $(32,65)$.

\section{Diagnosis}

Symptoms of chronic radiation cystitis are nonspecific, therefore other causes of haematuria, such as urinary tract infection, urolithiasis, anti-thrombotic agents, coagulopathies or malignancy, should be excluded. Laboratory investigations including full blood count, blood urea, serum creatinine and coagulation profile should be performed. General urine analysis and urine culture are the basis for the diagnosis of urinary tract infections, while urine cytology is a tool used in the diagnosis of high-grade urothelial tumours. Possible fistulas should be sought during the physical examination. In the next stage, the urinary tract should be assessed: upper, by ultrasonography or urography, and lower by means of cystoscopy. In addition, endoscopic examination allows the collection of samples for histopathological examination, which allows confirmation of the diagnosis and exclusion of the tumour process. During the biopsy, one should remember about impaired healing of the irradiated bladder wall and the risk of perforation. Urodynamic tests can help assess cystometric capacity, sphincter function, detrusor compliance, or the presence of vesicoureteral reflux.

\section{Management}

With the development of medicine, more and more therapeutic options are available to treat radiation cystitis. Part of the therapy is effective only for a short time and they cause various side effects. In addition, currently there are no standardized guidelines describing the algorithm for the management of radiation cystitis, which results, among others, from the lack of quality randomized studies.

Management methods can be divided into intravesical, systemic, ablative, hyperbaric oxygen and surgical techniques.

Currently, the type of treatment depends on the experience of the urologist, the availability of the method in the hospital, the severity of bleeding and the general condition of the patient. Patients with mild bleeding may only require conservative management, and in the case of massive bleeding, more aggressive management such as cystectomy may be necessary. In addition, comorbidities may disqualify the patient from general anaesthesia necessary for surgery or formalin instillation. Renal failure may limit the use of aluminium.

In general, treatment begins with stabilizing the general condition and conservative management. In the absence of effectiveness, minimally invasive methods such as intravesical instillations or endoscopic treatment are used. Surgical options should only be considered as a last resort (Figure 1).

\section{Acute radiation cystitis}

Because of the self-limiting nature, treatment of acute radiation cystitis is symptomatic. Anticholinergic drugs (e.g., oxybutynin) are mainly used. Alternatively, phenazopyridine or flavoxate may be prescribed $(32,65)$.

\section{Chronic radiation cystitis}

\section{Initial management}

Initial management depends on the severity of the haematuria and the general condition of the patient. In the case of hypovolemic shock, intravenous fluid resuscitation and blood transfusion are necessary $(30-32,69,70,72)$. If possible, anticoagulants and ASA should be discontinued, and coagulation disorders should be corrected $(30,75,76)$. The procedure to remove clots involves the introduction of a large (at least $22 \mathrm{Ch}$ ) transurethral catheter, copious bladder washout followed by intermittent or continuous irrigation of the bladder with saline $(18,30,32,70,72$ $74,77,78)$. Irrigation should continue until the urine is clear $(32,64)$. Leaving blood clots may cause urethral obstruction, urinary retention, and consequent perforation of the bladder $(31,64,69)$. Sometimes clot removal requires cystoscopy $(64,73)$. Most patients respond to conservative treatment, and in the absence of efficacy, alternative treatment options are needed $(32,70)$.

\section{Intravesical instillations}

Bladder therapy is usually carried out using aluminium or formalin. Due to insufficient data, other methods cannot be recommended as routine management of chronic radiation cystitis. These include the use of placental extract (79), 


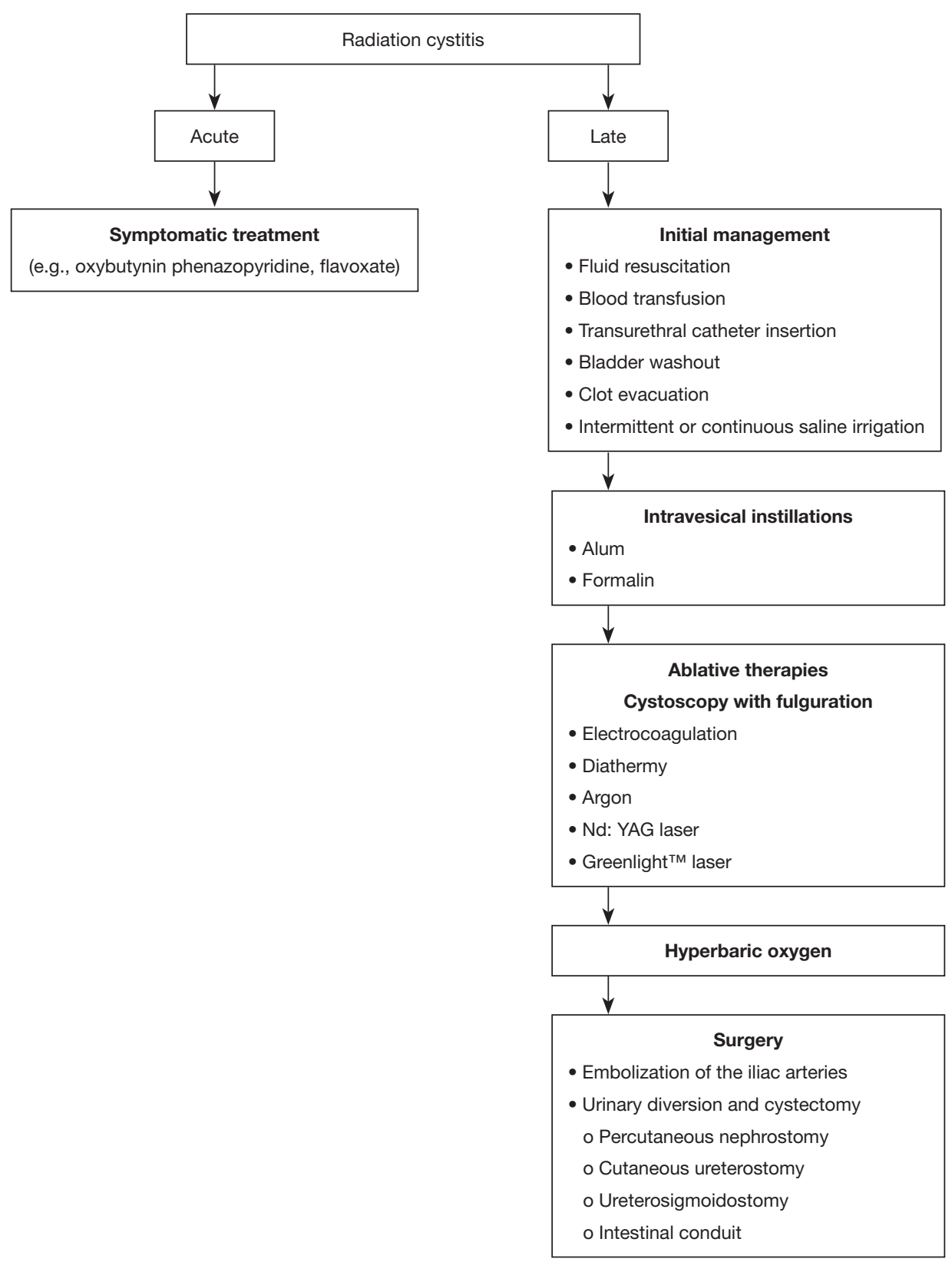

Figure 1 Management of radiation cystitis.

prostaglandins (80-82), silver nitrate (83-86), epsilon aminocaproic acid (87), hyaluronic acid (88), recombinant factor VII $(89,90)$, dexamethasone $(91)$, tacrolimus $(92,93)$.

\section{Alum}

Alum is a solution of aluminium ammonium sulphate or aluminium potassium sulphate. As an astringent, it causes protein precipitation on urothelium surfaces and in interstitial spaces. A decrease in capillary permeability and vasoconstriction occurs, which in effect leads to stopping bleeding (94). In the event of heavy bleeding, clot formation and recurrence of haematuria may occur (95). Typically, an infusion of $1 \%$ alum solution $(50 \mathrm{~g}$ alum dissolved in a 5 -liter bag of sterile water) is used at a rate of 200 $300 \mathrm{~mL} / \mathrm{h}(78,96)$. The procedure can be performed under local anaesthesia. The response rate ranges from $50 \%$ to 
$100 \%(52,77,78,94-100)$. Adverse events include suprapubic pain and bladder spasms that respond to treatment with analgesics and/or antispasmodics $(77,96)$. Urinary tract infection develops less often (96). Patients with impaired renal function are at risk of developing encephalopathy and acidosis, therefore monitoring of serum alum levels is recommended $(95,97,100)$. Due to the favourable toxicity profile, alum infusions are recommended as firstline treatment in the event of ineffective conservative treatment $(32,72)$.

\section{Formalin}

Formalin is a formaldehyde solution. The mechanism of its action is the precipitation of cellular proteins in the mucosa as well as occlusion and fixation of telangiectasia and small capillaries, which leads to stopping of haemorrhage. It causes protein hydrolysis and coagulation of the superficial tissues of the bladder mucosa $(78,101)$. The intravesical instillation of formalin causes severe suprapubic pain, so it is performed under general or regional anaesthesia (101-103). Prior to initiation of therapy, vesicoureteral reflux and bladder perforation should be excluded by cystography $(104,105)$. In patients with reflux, ureteric orifices should be sealed with a balloon to prevent damage to the ureters and kidneys (105-107). Formalin concentrations used are 1-10\%, however, maximum dilution is preferred because formalin toxicity increases with higher concentration $(103,105,108)$. The instillation time should not exceed 15 minutes (103). After the bladder is completely empty, the saline irrigation should be continued. The effectiveness of treatment ranges from $70 \%$ to $90 \%(101,103-105,108-111)$. However, this method is highly toxic. Adverse events include severe bladder spasm, ureter obstruction, hydronephrosis, and renal failure. Bladder wall fibrosis can lead to a decrease in its capacity and an increased frequency of urination. Formal reflux into the upper urinary tract leads to bilateral pyonephrosis with lethal sepsis $(102,103,105,108,109,112)$. Due to the high toxicity, formalin instillation should be used as a last resort before surgery, in the case of less invasive methods being ineffective $(32,64,66,102,104)$.

\section{Systemic therapies}

Systemic therapies are non-invasive, and treatment does not require hospitalization. However, the evidence for systemic therapies is of low quality and therefore cannot be recommended as routine management of chronic radiation cystitis. The general principle of their operation is to strengthen the protective polysaccharide layer of urothelium $(32,72,75,113)$. The compounds proposed in systemic therapy include pentosan polysulfate (114-116), WF10 $(117,118)$, conjugated oestrogen (119), tranexamic $\operatorname{acid}(120)$.

\section{Pentosan polysulfate}

Pentosan polysulphate is a synthetic polysaccharide sulphate that creates a protective coating on the bladder wall reducing the permeability and inflammatory response of urothelium. It is used sublingually at a dose of $100 \mathrm{mg} 3$ times a day. No adverse events were observed (114-116).

\section{WF10}

WF10 is diluted tetrachlorodecaoxide that induces natural immunity and counteracts the inflammatory process associated with submucosal endarteritis. It was used intravenously at a dose of $0.5 \mathrm{~mL} / \mathrm{kg}$, diluted in $250 \mathrm{~mL} 5 \%$ dextrose and administered over 2 hours. The therapy was continued every day for 5 consecutive days, every 3 weeks for $2-4$ cycles. Complete response was $74-88 \%$. No adverse events were observed $(117,118)$.

\section{Hyperbaric oxygen}

Hyperbaric oxygen therapy involves the administration of $100 \%$ oxygen at a higher than atmospheric pressure in a special chamber. This allows maximum haemoglobin saturation and better oxygen diffusion in the tissues. Neoangiogenesis is stimulated and fibroblasts are activated and proliferated. New vessels provide oxygen to ischemic tissue, facilitating tissue reepithelialisation and healing (71,74,121-123). Various hyperbaric oxygen therapy regimens are used. Generally, 100\% oxygen is administered at a 1.5-2.5 atmospheric pressure for 45-120 minutes, which gives additional time for compression and decompression. To reduce the risk of oxygen toxicity, a 5-minute "air gap" can be introduced every half hour. The therapy takes place every day and usually includes $20-40$ sessions $(32,67,124)$. Complete resolution of haematuria occurs in $34-96 \%$ of patients $(23,63,121,122,124-136)$. This method of treatment avoids surgical treatment and at the same time has no negative effect on the bladder wall, which occurs when using, for example, formalin. Adverse events are rare and include ear and sinus barotrauma, convulsions caused by toxic oxygen, and claustrophobia $(71,121,125,128,132,133)$. The disadvantages of this method include the limited availability and nuisance caused by daily sessions and a long 
period of treatment (72). Hyperbaric oxygen therapy may be an alternative to surgery in the event of resistance to conventional therapy (32).

\section{Ablative therapies}

In the case of resistance to intravesical instillations, cystoscopy with fulguration of bleeding points is recommended (62). Treatment is performed under general or spinal anaesthesia with electrocoagulation, diathermy, argon, Nd: YAG laser or Greenlight ${ }^{\mathrm{TM}}$ potassium-titanylphosphate laser (137-142). Argon and the Greenlight ${ }^{\mathrm{TM}}$ laser have a more favourable safety profile due to the smaller penetration depth compared to the Nd: YAG laser (138-140). Fulguration cystoscopy has a high efficiency, ranging from $75 \%$ to $100 \%$ (137-142). Adverse events associated with this procedure include bladder perforation and/or fistula formation (137-139,142).

\section{Other intravesical therapies}

Other intravesical therapies include transurethral placement of a large balloon in the bladder (hydrodistension) $(143,144)$, and botulinum toxin A injections into the bladder wall (145). Due to insufficient data, these methods are not recommended as routine management of chronic radiation cystitis $(32,72,113)$.

\section{Surgical interventions}

Surgical treatment should be treated as a last resort in the case of resistance to other forms of therapy, because it is associated with high morbidity and mortality rates. It includes selective embolization of the internal iliac arteries, urinary drainage and cystectomy.

\section{Embolization}

Embolization of the iliac arteries is characterized by high efficiency reaching $100 \%$. Complications of the therapy include necrosis of the skin, bladder, gluteal muscles, rectum, lumbosacral plexus or sciatic nerve palsy. The most common complication is gluteal pain secondary to obstruction of the upper gluteal artery. With the introduction of new embolization particles and superselective embolization, the rate of complications has decreased (146-151).

\section{Urinary diversion and cystectomy}

Urinary drainage methods include percutaneous nephrostomy, cutaneous ureterostomy, ureterosigmoidostomy, and intestinal conduit formation (152-155). The transverse colon conduit is the preferred method because the transverse colon, unlike the small intestine, is not in the irradiation area (153). Complications associated with urinary diversion include pyocystis, haemorrhage, pain and neoplastic transformation $(156,157)$. Due to the high rate of adverse events exceeding $50 \%$, simultaneous cystectomy should be considered $(156,158)$. However, it should be remembered that cystectomy is associated with a high risk of perioperative complications and mortality. In addition, many patients with refractory radiation cystitis are elderly with many comorbidities, which may need to be considered for qualification for surgery $(159,160)$.

\section{Urinary fistulae}

Urinary fistulae are rare complications of radiation therapy but are considered potentially severe and the most difficult to treat $(19,161)$. They can occupy the entire urinary system, as well as the gastrointestinal tract or reproductive organs, and can occur up to 20-30 years after treatment (161-163). Vesicovaginal fistulae develop in $1-10 \%$ of patients undergoing pelvic radiotherapy $(31,162,164)$. Up to $3 \%$ of patients treated with radiation for prostate cancer develop fistulae, and the most common are rectourethral and rectovesical (161,165-169).

\section{Pathophysiology}

As previously described, radiation causes endarteritis and, consequently, hypoxia, necrosis and fibrosis $(167,170)$. The accumulation of collagen in the mucosa of the ureters and the bladder leads to a loss of compliance and a subsequent increase in wall tension (31). Together with tissue necrosis caused by hypoxia, these changes lead to fistula formation $(12,16,68,70,71,161,165,171)$. Radiotherapy-related fistulae are usually large and multiple and are most often located within the bladder trigone, since this region usually receives the highest dose of radiation $(165,172)$.

\section{Localisation}

Urinary fistulae can potentially develop throughout the entire urinary tract, the lower digestive tract and the reproductive system. The most common are vesicovaginal fistula in women and rectourethral fistula in men (31). 
Both sexes also develop fistulae between the urinary tract and the gastrointestinal tract, which most often occupy the colon (e.g., enterovesical) $(161,170,173)$. Rare radiation fistulas include vesicocutaneous, ureteroarterial and prostatosymphyseal $(19,167,174-177)$.

\section{Clinical presentation}

Urinary fistula can be asymptomatic and accidentally detected. Symptoms depend on the location of the fistula. Vesicovaginal fistula is manifested by urine leakage from the vagina, recurrent urinary tract infections and dermatitis of the genital area $(31,162,178)$. In the case of fistulae between the urinary tract and the gastrointestinal tract (enterovesical, rectourethral), patients complain of pneumaturia, fecaluria, recurrent urinary tract infections, haematuria, lower urinary tract symptoms (frequency, urgency), as well as pain in the suprapubic area $(165,174,179-181)$. Skin fistulae manifest themselves as urine leakage onto the body surface $(167,176)$. Recurrent urinary tract infections in the course of fistulae are associated with the risk of developing sepsis $(167,179)$.

\section{Diagnosis}

Diagnosis of fistulae begins with physical examination, including gynaecological examination in women. A general urine test and urine culture are performed. The basis for diagnosis is imaging tests that allow visualization of the fistula canal, its size, as well as assessment of adjacent tissues and detection of accompanying pathologies (e.g., bladder neck stenosis) and planning of surgical treatment. The most commonly used are retrograde urethrography, voiding cystourethrography, intravenous urography, barium ingot, cystoscopy, and ultrasound. The methylene blue test, in which the dye is introduced into the bladder or rectum is also helpful. Cystoscopy is the preferred examination, during which the guidewire can be passed through the canal and the material for histopathological examination can be taken. Computed tomography and magnetic resonance imaging are considered the most sensitive imaging tests in fistula diagnostics.

\section{Management}

In the case of radiation urinary fistulae, conservative treatment is ineffective and the basis for treatment is surgery $(178,182-184)$. The type of surgery depends on the location and extent of the fistula. Due to ischemia of surrounding tissues, postoperative healing may be impaired, therefore, in order to restore the function of the genitourinary system or gastrointestinal tract, complicated reconstruction techniques are often necessary $(161,167,185)$. The basis of surgical management is to ensure adequate nutrition of the tissue surrounding the fistula (161). Treatment is associated with a high percentage of failures and relapses (7).

\section{Vesicovaginal fistula}

The treatment of vesicovaginal fistulae can be carried out transvaginal or transabdominal using a variety of surgical techniques (161). In the presence of fistulae within the other pelvic organs or if additional urological procedures are required, transabdominal approach is preferred. Combined transvaginal and transabdominal access may be used in severe and recurrent cases $(162,178)$. Regardless of surgical approach, the most important element is to provide blood supply and nutrition to the ischemic and fibrotic tissue surrounding the fistula. For this purpose, omental and peritoneal flaps or labial fat are used during fistula repair $(16,161,186-188)$. The effectiveness of treatment ranges from $40 \%$ to $100 \%$ (189-191). In case the surgery is ineffective or technically impossible, urine drainage is recommended $(7,162,178)$.

\section{Rectourethral fistula}

Treatment of the rectourethral fistula begins with intestinal and urinary diversion to reduce inflammation in the fistula and surrounding tissues prior to surgery and therefore reduce the risk of sepsis $(19,165,192)$. The type of surgery depends on the general condition of the patient, life expectancy, local anatomy, as well as whether the return of urinary and gastrointestinal tract function is expected. Ultimately, the goal is to close the fistula and restore bladder and bowel function. Transperineal access is preferred as it allows greater urethral and rectal exposure. Abdominal access is less common (192-195). Due to ischemia of the tissues surrounding the fistula, to allow healing, a graft from the buccal mucosa or vascularized lobe is placed in the plane between the urethra and the rectum. The most commonly used lobe is the gracilis muscle, the less common are omentum, gluteus maximus muscle, abdominal rectus muscle and dartos $(165,169,182,183,193,196-198)$. During surgery, due to tissue fibrosis, there is a risk of damage to adjacent structures such as the external urethral sphincter and the external anal sphincter $(7,161,193)$. The effectiveness of therapy reaches $84 \%$ (193). In cases that do not suggest a return to the function of the urinary and 
gastrointestinal tract, cystoprostatectomy and proctectomy with subsequent urinary and intestinal diversion are used $(9,19,165,192)$.

\section{Ureteral stricture}

Ureteral stricture is a rare but serious complication of radiation therapy. Diagnosis is often late, and treatment is complicated $(199,200)$. The overall incidence of stenosis is $0.4-2.7 \%(21,201)$. Strictures most often occur after radiotherapy for cervical cancer and are diagnosed in 3.3\% of patients within 25 years after the end of cancer treatment $(22,33)$. The average latency period is 16.8 years (21). Less often they are a complication of prostate cancer irradiation, with an incidence of $1-2.7 \%(75,202,203)$. Ureteral stricture is most often located $4-6 \mathrm{~cm}$ proximal to the ureteric orifice, because of its proximity to the area exposed to the greatest radiation $(21,33,60)$. Due to the fact that stenosis can occur even 20 years after the end of treatment, young patients are at increased risk of developing this complication (33).

\section{Pathophysiology}

Changes in the ureters caused by radiation are the same as in the urinary bladder. Endarteritis and ischemia occur, which induces tissue fibrosis. Impaired tissue healing leads to atrophy and contraction in the ureter and, as a result, ureter stenosis develops $(12,20,204)$.

\section{Clinical presentation}

Symptoms depend on the extent to which the ureter is narrowed and whether the stenosis is one or both sides (20). Most cases are asymptomatic and accidentally diagnosed $(60,199,205)$. The only manifestation may be hydronephrosis or impaired renal function in laboratory tests. Flank pain is a rare symptom $(60,205)$. Long-term, unrecognized ureteral stricture carries the risk of the development of vesicoureteral reflux and recurrent upper urinary tract infections complicated by life-threatening urosepsis $(18,20,21,205)$. As a result, there may be a progressive loss of kidney function with the development of hypertension $(21,60,206)$.

\section{Diagnosis}

During diagnostics, laboratory tests may show elevated creatinine and urea nitrogen. Imaging tests include contrast studies, computed tomography and MAG3 renography, which allow to assess the degree of ureter stenosis and function of the affected kidney. Cancer recurrence should always be excluded. In the case of tumour recurrence, stenosis usually appears within 5 years. If differentiation is not possible based on imaging tests, a biopsy is required $(18,33,205,207,208)$.

\section{Management}

The management of ureteral strictures should be initiated by ensuring free urine flow by means of a percutaneous nephrostomy or ureteral catheters, which prevents upper urinary tract infections and deterioration of kidney function $(18,21,60,75)$. Further management depends on the patient's general condition, comorbidities, age, prognosis, location and length of stenosis, the presence of other radiation complications and the patient's preferences $(20,21)$. Therapy options include minimally invasive procedures, reconstructive techniques, surgical urinary diversion or permanent drainage using nephrostomy or ureteral stents $(16,19-21,60)$. The effectiveness of treatment reaches $67 \%$ (Figure 2) (16).

Minimally invasive treatment is an alternative to open surgery and include the use of a balloon, catheter dilatation and holmium laser endoureterotomy (205).

The method of choice for the treatment of ureteral stricture is surgery involving reconstruction or urinary diversion that provide long-term results (21). In rare cases, when stenosis is very short, end-to-end anastomosis may be used (20,21). Distal defects can be treated with resection and Psoas hitch or Boari flap ureterocystoneostomy $(7,16,21,75,206,209,210)$. The use of an omental flap has been described to improve healing by providing blood and nutrition (210). Alternatively, the ureter can be anastomosed to a contralateral ureter by transureteroureterostomy (21,211). For long stenoses, the ureter is reconstructed using the small intestine segment, large intestine segment or the appendix (16,20,21,212-214). If the capacity of the bladder is small, urine drainage with ileal, jejunal or transverse colonic conduit is performed $(16,19,21,75)$. The ileum segment is most commonly used, but the condition for successful surgery is the selection of the segment of the intestine that was not in the irradiation field $(7,21,212)$.

In patients whose general condition does not allow surgery or who do not want to undergo surgery, 


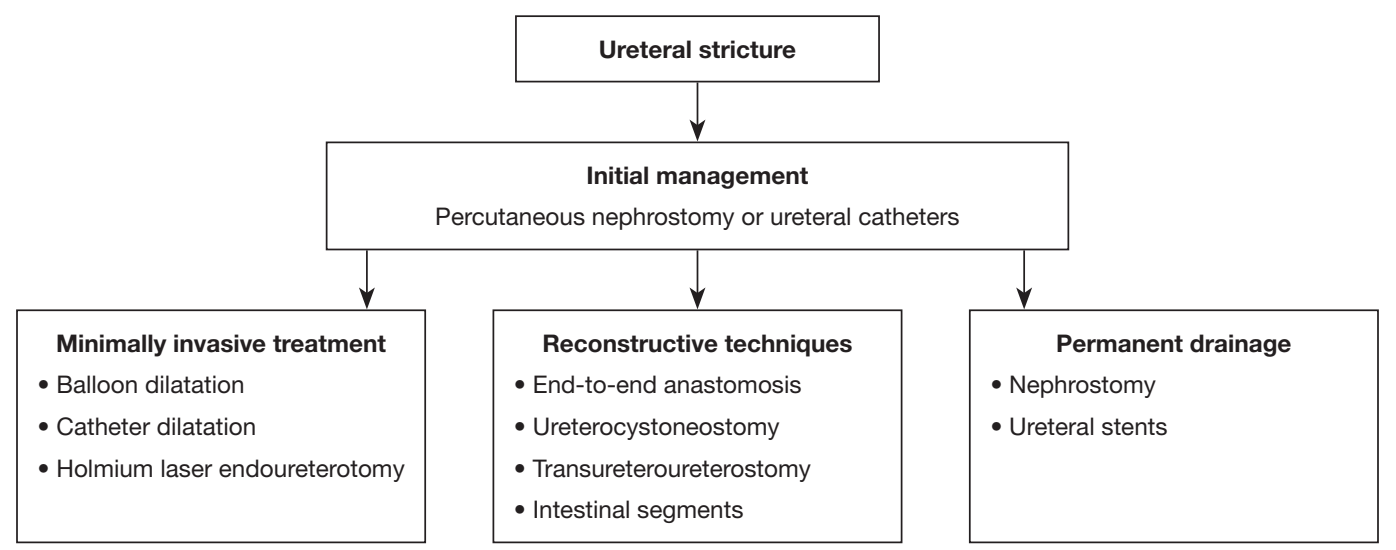

Figure 2 Management of ureteral stricture.

nephrostomy is created or stents are introduced, but these procedures are associated with a high risk of complications $(19-21,207)$.

\section{Urethral stricture}

Urethral stricture is a serious complication that can lead to voiding dysfunction and, as a consequence, damage to the upper urinary tract (215). Most often, the narrowing is caused by radiation therapy for prostate cancer $(6,12)$. At the same time, it is the most common long-term side effect of this type of prostate cancer therapy (6). To date, only one case of urethral stricture has been reported among women after radiation therapy for cervical cancer (216).

The overall incidence of urethral strictures after radiotherapy for prostate cancer is $2.2 \%$, of which $1.5 \%$ after external beam radiotherapy, $1.9 \%$ after brachytherapy, and $4.9 \%$ after combination therapy $(6,217,218)$. They are usually observed within 1-3 years after treatment $(215,217,219,220)$. More than $90 \%$ of strictures are located in the bulbomembranous urethra, but this phenomenon remains unclear because this area receives a lower dose of radiation than the prostate urethra $(6,215,217,220,221)$. The median stenosis length is between 1 and $3.5 \mathrm{~cm}$ (215,222-224).

The most important risk factor for developing urethral stricture is total radiation dose $(202,218,220,225)$. Therefore, the combination of brachytherapy and external beam radiation therapy significantly increases the incidence of stenosis $(217,218,226)$. Other risk factors include previous transurethral resection of the prostate, patient's age and comorbidities such as hypertension and diabetes $(221,225-228)$.

\section{Pathophysiology}

The processes leading to the development of urethral stricture are the same as in radiation cystitis and ureteral stricture. Endarteritis develops, followed by hypoxia and tissue necrosis, and collagen deposition stimulation. As a result, atrophy, contraction and fibrosis occur, which causes urethral stenosis $(12,217,229)$.

\section{Clinical presentation}

The main complaints of urethral stricture are lower urinary tract symptoms, both irritant and obstructive. Other symptoms include recurrent urinary tract infections, haematuria, and bladder stones. They worsen the patient's quality of life and, if left untreated, can lead to damage to the upper urinary tract $(215,217,230-232)$.

\section{Diagnosis}

Diagnostics include anamnesis, physical examination, laboratory tests such as estimation of kidney function, urinalysis and urine culture. In the differentiation with local tumour recurrence, serum prostate-specific antigen level assessment is used. Urodynamic examination allows the measurement of urinary bladder capacity and postvoid residual urine volume. Radiological studies such as retrograde urethrography and voiding cystourethrography are recommended to delineate the length, location, severity and complexity of the stenosis. The next stage of diagnostics 


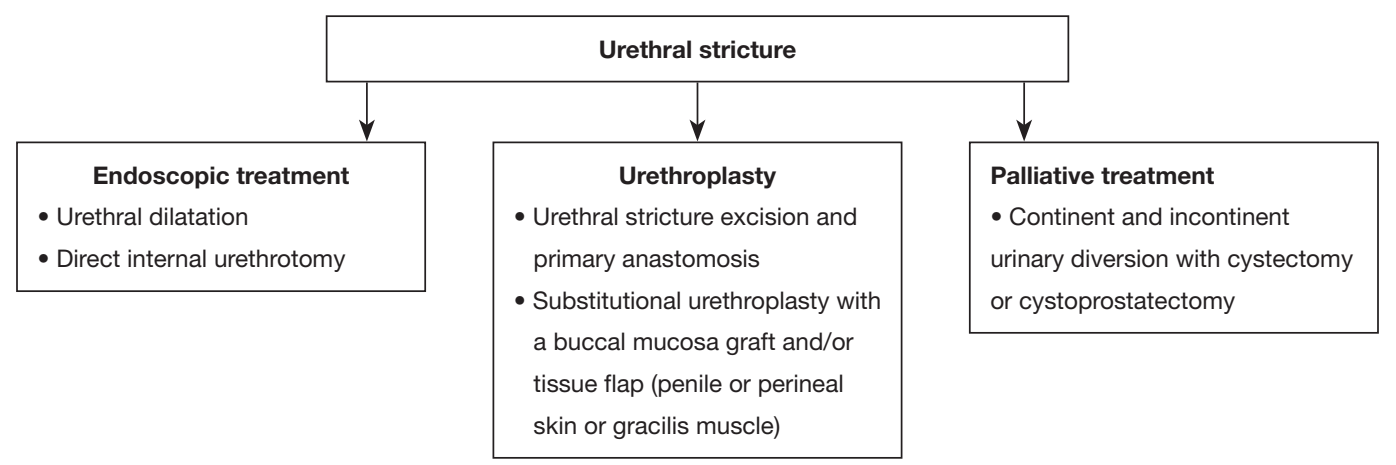

Figure 3 Management of urethral stricture.

is urethrocystoscopy, which, in addition to visualizing the location of the stenosis, allows to assess the function of the external sphincter.

\section{Management}

Treatment of urethral stricture is difficult and associated with a high risk of complications and recurrences, which is caused by impaired healing of ischemic and fibrotic tissues and the close proximity of the sphincter. Management methods include endoscopic techniques, open surgery and palliative procedures. The choice of treatment depends on the patient's general condition, features of stenosis, sphincter and bladder function, and patient preferences (Figure 3) $(6,9,75,215,218,233,234)$.

Endoscopic treatment such as urethral dilatation and direct internal urethrotomy are minimally invasive but are associated with a high (over $50 \%$ ) risk of recurrence $(19,191,215,221,235)$. Repetition of procedures leads to lengthening of the stenosis, exacerbation of periurethral fibrosis, delaying and complicating subsequent urethroplasty (236). Therefore, the method is recommended for patients who are unable or unwilling to undergo surgery (6,219,237-239).

Urethroplasty is the basis of surgical treatment. Urethral stricture excision and primary anastomosis is the treatment of choice for short stenoses (less than $2-3 \mathrm{~cm}$ ), and the rate of effectiveness is $70-97 \%(215,219,222,223,230,233,240$ 243). For longer stenoses, substitutional urethroplasty with a buccal mucosa graft and/or tissue flap (penile or perineal skin or gracilis muscle) is used $(215,219,240)$. The effectiveness of the procedure is $70-83 \%$ $(222,224,230,241,244)$. Both procedures are associated with a risk of urinary incontinence, which occurs in $7-40 \%$ of patients after excision and primary anastomosis, and in $10.5-44 \%$ after urethroplasty using a buccal mucosa graft $(6,222-224,230,242,245)$. In this case, artificial sphincter implantation is used $(215,224,230,244)$.

Palliative methods are reserved for patients who, due to their general condition, do not qualify for surgery or whose repeated attempts to repair the stenosis have been unsuccessful. The management includes continent and incontinent urinary diversion with cystectomy or cystoprostatectomy $(6,19,159,215,219,233,238,246)$.

\section{Secondary primary cancer}

Radiation-induced second primary tumours are a rare and late adverse event that occurs after a long latency period (more than 5 years after radiotherapy) in regions exposed to radiation. They have a different histological type from the primary tumour and are neither a recurrence nor a metastasis (247-252). Carcinogenesis is caused by the accumulation of mutagenic genetic changes caused by radiation $(12,249)$.

The risk of developing secondary primary tumours after irradiation of pelvic malignancies is slightly higher (250,253-261). Some studies have reported an increased risk of developing bladder cancer $(253,254,256,260-265)$. For the treatment of prostate cancer and rectal cancer, the results are inconclusive $(255,266-271)$.

An interesting relationship that has been observed is a reduction in the risk of developing prostate cancer in patients undergoing radiotherapy for rectal cancer $(254,255,266,267,272,273)$. Probably the simultaneous irradiation of the prostate can prevent or delay the development of prostate cancer $(255,266,272)$. In addition, the dissipated dose of radiation for the testicles can lead to 
a decrease in testosterone, which limits the development of prostate tumour $(274,275)$.

However, due to the described risk of developing secondary cancers, even after 40 years from the end of treatment, long-term follow-up of patients undergoing radiation therapy is important (253).

\section{Conclusions}

In conclusion, radiotherapy is one of the main methods of treating patients suffering from cancer. Despite its high effectiveness, it causes damage to adjacent healthy tissues, which is associated with the development of complications. Due to the pelvic anatomy, irradiation of gastrointestinal and genitourinary cancers is often associated with side effects from the urinary tract. Adverse events significantly degrade the patient's quality of life, and in severe cases can be life threatening to the patient. Because of impaired tissue healing, the treatment of radiation urological complications is a challenge for urologists and often requires complicated reconstruction techniques. Maintaining renal function and improving the patient's quality of life are the main therapeutic goals. Unfortunately, there are currently no general recommendations and the available treatment methods are associated with a high percentage of relapses and complications. Therefore, further high-quality research is needed to better understand the pathophysiology of tissue radiation damage, to discover and evaluate the effectiveness of new therapeutic options. This will allow for the development of an effective therapeutic path and international recommendations.

Due to the continuous increase in the effectiveness of cancer treatments and the extension of patients' lives, complications of radiation therapy are becoming an increasingly important clinical problem. The time from the end of treatment to the appearance of adverse events may be up to several years, so monitoring and early detection are important. Observation after oncological treatment allows not only to detect recurrence of the neoplastic disease, but also to diagnose complications related to the treatment method, including radiotherapy. During regular follow-up visits with the help of laboratory tests (serum and urine tests), imaging and endoscopic examinations, it is possible to monitor and early detect radiation complications. Due to the fact that urological complications of radiotherapy also complicate nonurological pelvic cancers, these patients should be considered for regular urological care.

\section{Acknowledgments}

Funding: None.

\section{Footnote}

Reporting Checklist: The authors have completed the Narrative Review reporting checklist. Available at http:// dx.doi.org/10.21037/tcr-20-2589

Conflicts of Interest: All authors have completed the ICMJE uniform disclosure form (available at http://dx.doi. org/10.21037/tcr-20-2589). The authors have no conflicts of interest to declare.

Ethical Statement: The authors are accountable for all aspects of the work in ensuring that questions related to the accuracy or integrity of any part of the work are appropriately investigated and resolved.

Open Access Statement: This is an Open Access article distributed in accordance with the Creative Commons Attribution-NonCommercial-NoDerivs 4.0 International License (CC BY-NC-ND 4.0), which permits the noncommercial replication and distribution of the article with the strict proviso that no changes or edits are made and the original work is properly cited (including links to both the formal publication through the relevant DOI and the license). See: https://creativecommons.org/licenses/by-nc-nd/4.0/.

\section{References}

1. Zeman EM, Schreiber EC, Tepper JE. Basics of Radiation Therapy. In: Niederhuber JE, Armitage JO, Doroshow JH, et al. editors. Abeloff's Clinical Oncology Sixth Edition. Philadelphia; 2020:431-60.e3.

2. Baskar R, Lee KA, Yeo R, et al. Cancer and radiation therapy: Current advances and future directions. Int J Med Sci 2012;9:193-9.

3. Delaney G, Jacob S, Featherstone C, et al. The role of radiotherapy in cancer treatment: Estimating optimal utilization from a review of evidence-based clinical guidelines. Cancer 2005;104:1129-37.

4. Begg AC, Stewart FA, Vens C. Strategies to improve radiotherapy with targeted drugs. Nat Rev Cancer. 2011;11:239-53. 
5. Schaue D, Mcbride WH. Opportunities and challenges of radiotherapy for treating cancer. Nat Rev Clin Oncol. 2015;12:527-40.

6. Rosenbaum CM, Engel O, Fisch M, et al. Harnröhrenstrikturen nach Strahlentherapie. Urologe A 2017;56:306-12.

7. Kocot A, Riedmiller H. Therapie von Strahlenspätschäden am Harntrakt. Urologe A 2015;54:1765-71.

8. Sadeghi M, Enferadi M, Shirazi A. External and internal radiation therapy: Past and future directions. J Cancer Res Ther 2010;6:239-48.

9. Stone HB, Coleman CN, Anscher MS, et al. Effects of radiation on normal tissue: Consequences and mechanisms. Lancet Oncol 2003;4:529-36.

10. Flannigan RK, Baverstock RJ. Management of postradiation therapy complications among prostate cancer patients: A case series. Can Urol Assoc J 2014;8:E632-6.

11. Kwek JW, Iyer RB, Dunnington J, et al. Spectrum of imaging findings in the abdomen after radiotherapy. AJR Am J Roentgenol 2006;187:1204-11.

12. Russell NS, Bartelink H. Radiotherapy: The last 25 years. Cancer Treat Rev 1999;25:365-76.

13. Citrin D, Cotrim AP, Hyodo F, et al. Radioprotectors and Mitigators of Radiation-Induced Normal Tissue Injury. Oncologist 2010;15:360-71.

14. Mortezaee K, Shabeeb D, Musa AE, et al. Metformin as a Radiation Modifier; Implications to Normal Tissue Protection and Tumor Sensitization. Curr Clin Pharmacol 2019;14:41-53.

15. Dörr W, Hendry JH. Consequential late effects in normal tissues. Radiother Oncol 2001;61:223-31.

16. Toia B, Seth J, Ecclestone H, et al. Outcomes of reconstructive urinary tract surgery after pelvic radiotherapy. Scand J Urol 2019;53:156-60.

17. Bentzen SM, Dörr W, Anscher MS, et al. Normal tissue effects: reporting and analysis. Semin Radiat Oncol 2003;13:189-202.

18. Li F, Guo H, Qiu H, et al. Urological complications after radical hysterectomy with postoperative radiotherapy and radiotherapy alone for cervical cancer. Medicine (Baltimore) 2018;97:e173.

19. Ma JL, Hennessey DB, Newell BP, et al. Radiotherapyrelated complications presenting to a urology department: a more common problem than previously thought? BJU Int 2018;121 Suppl 3:28-32.

20. Kranz J, Brandt AS, Anheuser P, et al. Radiogene Harnleiterstrikturen: Mögliche Therapieoptionen. Urologe A 2017;56:322-8.
21. Gellrich J, Hakenberg OW, Oehlschläger S, et al. Manifestation, latency and management of late urological complications after curative radiotherapy for cervical carcinoma. Onkologie 2003;26:334-40.

22. Elliott SP, Malaeb BS. Long-term urinary adverse effects of pelvic radiotherapy. World J Urol 2011;29:35-41.

23. Bevers RFM, Kurth KH, Bakker DJ. Hyperbaric oxygen treatment for haemorrhagic radiation cystitis. Lancet 1995;346:803-5.

24. Dautruche A, Delouya G. A contemporary review about the management of radiation-induced hemorrhagic cystitis. Curr Opin Support Palliat Care 2018;12:344-50.

25. Dean AL. Ulceration of the urinary bladder as a late effect of radium applications to uterus. JAMA 1927;89:1121-4.

26. Cox JD, Stetz JA, Pajak TF. Toxicity criteria of the Radiation Therapy Oncology Group (RTOG) and the European organization for research and treatment of cancer (EORTC). Int J Radiat Oncol Biol Phys 1995;31:1341-6.

27. Common Terminology Criteria for Adverse Events (CTCAE) [Internet]. National Cancer Institute, Cancer Therapy Evaluation Program; c2020 [cited 2020 Jul 1]. Available online: https://ctep.cancer.gov/ protocolDevelopment/electronic_applications/ctc. htm\#ctc_500

28. LENT SOMA scales for all anatomic sites. Int J Radiat Oncol Biol Phys 1995;31:1049-91.

29. Power DA. Late effects of radiotherapy: How to assess and improve outcomes. Br J Radiol 2005;78:150-2.

30. Crew JP, Jephcott CR, Reynard JM. Radiation-induced haemorrhagic cystitis. Eur Urol 2001;40:111-23.

31. Lobo N, Kulkarni M, Hughes S, et al. Urologic Complications Following Pelvic Radiotherapy. Urology 2018;122:1-9.

32. Smit SG, Heyns CF. Management of radiation cystitis. Nat Rev Urol 2010;7:206-14.

33. McIntyre JF, Eifel PJ, Levenback C, et al. Ureteral stricture as a late complication of radiotherapy for stage IB carcinoma of the uterine cervix. Cancer 1995;75:836-43.

34. Nishimura T, Suzuki K, Iijima M, et al. Spontaneous rupture of bladder diverticulum after postoperative radiotherapy for carcinoma of the uterine cervix: A case report. Radiat Med 2000;18:261-5.

35. Zelefsky MJ, Cowen D, Fuks Z, et al. Long term tolerance of high dose three-dimensional conformal radiotherapy in patients with localized prostate carcinoma. Cancer 1999;85:2460-8.

36. Zietman AL, DeSilvio ML, Slater JD, et al. Comparison 
of conventional-dose vs high-dose conformal radiation therapy in clinically localized adenocarcinoma of the prostate: A randomized controlled trial. JAMA 2005;294:1233-9.

37. Lawton CA, Won M, Pilepich MV, et al. Long-term treatment sequelae following external beam irradiation for adenocarcinoma of the prostate: analysis of RTOG studies 7506 and 7706. Int J Radiat Oncol Biol Phys 1991;21:935-9.

38. Zelefsky MJ, Wallner KE, Ling CC, et al. Comparison of the 5-year outcome and morbidity of three-dimensional conformal radiotherapy versus transperineal permanent iodine-125 implantation for early-stage prostatic cancer. J Clin Oncol 1999;17:517-22.

39. Peeters ST, Heemsbergen WD, Koper PC, et al. Doseresponse in radiotherapy for localized prostate cancer: results of the Dutch multicenter randomized phase III trial comparing 68 Gy of radiotherapy with 78 Gy. J Clin Oncol 2006;24:1990-6.

40. Peeters STH, Heemsbergen WD, Van Putten WLJ, et al. Acute and late complications after radiotherapy for prostate cancer: Results of a multicenter randomized trial comparing 68 Gy to 78 Gy. Int J Radiat Oncol Biol Phys 2005;61:1019-34.

41. Keyes M, Miller S, Moravan V, et al. Predictive Factors for Acute and Late Urinary Toxicity After Permanent Prostate Brachytherapy: Long-Term Outcome in 712 Consecutive Patients. Int J Radiat Oncol Biol Phys 2009;73:1023-32.

42. Anderson JF, Swanson DA, Levy LB, et al. Urinary Side Effects and Complications After Permanent Prostate Brachytherapy: The MD Anderson Cancer Center Experience. Urology 2009;74:601-5.

43. Efstathiou JA, Bae K, Shipley WU, et al. Late pelvic toxicity after bladder-sparing therapy in patients with invasive bladder cancer: RTOG 89-03, 95-06, 97-06, 9906. J Clin Oncol 2009;27:4055-61.

44. Fokdal L, Høyer M, Meldgaard P, et al. Long-term bladder, colorectal, and sexual functions after radical radiotherapy for urinary bladder cancer. Radiother Oncol 2004;72:139-45.

45. Henningsohn L, Wijkström H, Dickman PW, et al. Distressful symptoms after radical radiotherapy for urinary bladder cancer. Radiother Oncol 2002;62:215-25.

46. Majewski $W$, Tarnawski R. Acute and Late Toxicity in Radical Radiotherapy for Bladder Cancer. Clin Oncol (R Coll Radiol) 2009;21:598-609.

47. Viswanathan AN, Lee LJ, Eswara JR, et al. Complications of pelvic radiation in patients treated for gynecologic malignancies. Cancer 2014;120:3870-83.

48. Eifel PJ, Levenback C, Wharton JT, et al. Time course and incidence of late complications in patients treated with radiation therapy for FIGO Stage IB carcinoma of the uterine cervix. Int J Radiat Oncol Biol Phys 1995;32:1289-300.

49. Lorvidhaya V, Tonusin A, Changwiwit W, et al. Highdose-rate afterloading brachytherapy in carcinoma of the cervix: An experience of 1992 patients. Int J Radiat Oncol Biol Phys 2000;46:1185-91.

50. Pinn-Bingham M, Puthawala AA, Syed AMN, et al. Outcomes of high-dose-rate interstitial brachytherapy in the treatment of locally advanced cervical cancer: Longterm results. Int J Radiat Oncol Biol Phys 2013;85:714-20.

51. Georg P, Boni A, Ghabuous A, et al. Time course of late rectal- and urinary bladder side effects after MRI-guided adaptive brachytherapy for cervical cancer. Strahlenther Onkol 2013;189:535-40.

52. Takeshi K, Katsuyuki K, Yoshiaki T, et al. Definitive radiotherapy combined with high-dose-rate brachytherapy for stage III carcinoma of the uterine cervix: Retrospective analysis of prognostic factors concerning patient characteristics and treatment parameters. Int J Radiat Oncol Biol Phys 1998;41:319-27.

53. Kapp KS, Stuecklschweiger GF, Kapp DS, et al. Carcinoma of the cervix: Analysis of complications after primary external beam radiation and Ir-192 HDR brachytherapy. Radiother Oncol 1997;42:143-53.

54. Creutzberg CL, Van Putten WLJ, Koper PCM, et al. Surgery and postoperative radiotherapy versus surgery alone for patients with stage-1 endometrial carcinoma: Multicentre randomised trial. Lancet 2000;355:1404-11.

55. Keys HM, Roberts JA, Brunetto VL, et al. A phase III trial of surgery with or without adjunctive external pelvic radiation therapy in intermediate risk endometrial adenocarcinoma: A Gynecologic Oncology Group study. Gynecol Oncol 2004;92:744-51.

56. Roszak A, Wareńczak-Florczak Z, Bratos K, et al. Incidence of radiation toxicity in cervical cancer and endometrial cancer patients treated with radiotherapy alone versus adjuvant radiotherapy. Rep Pract Oncol Radiother 2012;17:332-8.

57. Kucera H, Vavra N, Weghaupt K. Benefit of external irradiation in pathologic stage I endometrial carcinoma: A prospective clinical trial of 605 patients who received postoperative vaginal irradiation and additional pelvic irradiation in the presence of unfavorable prognostic factors. Gynecol Oncol 1990;38:99-104. 
58. Nguyen TV, Petereit DG. High-dose-rate brachytherapy for medically inoperable stage I endometrial cancer. Gynecol Oncol 1998;71:196-203.

59. Sauer R, Becker H, Hohenberger W, et al. Preoperative versus postoperative chemoradiotherapy for rectal cancer. N Engl J Med 2004;351:1731-40

60. Wit EMK, Horenblas S. Urological complications after treatment of cervical cancer. Nat Rev Urol 2014;11:110-7.

61. deVries CR, Freiha FS. Hemorrhagic cystitis: A review. J Urol 1990;143:1-9.

62. Levenback C, Eifel PJ, Burke TW, et al. Hemorrhagic cystitis following radiotherapy for stage ib cancer of the cervix. Gynecol Oncol 1994;55:206-10.

63. Degener S, Strelow H, Pohle A, et al. Hyperbare Sauerstofftherapie bei hämorrhagischer Strahlenzystitis nach Prostatakarzinom. Urologe A 2012;51:1735-40.

64. Zwaans BMM, Lamb LE, Bartolone S, et al. Cancer survivorship issues with radiation and hemorrhagic cystitis in gynecological malignancies. Int Urol Nephrol 2018;50:1745-51.

65. Marks LB, Carroll PR, Dugan TC, et al. The response of the urinary bladder, urethra, and ureter to radiation and chemotherapy. Int J Radiat Oncol Biol Phys 1995;31:1257-80.

66. Zwaans BMM, Nicolai HG, Chancellor MB, et al. Challenges and Opportunities in Radiation-induced Hemorrhagic Cystitis. Rev Urol 2016;18:57-65.

67. Zwaans BMM, Chancellor MB, Lamb LE. Modeling and treatment of radiation cystitis. Urology 2016;88:14-21.

68. Denton AS, Clarke N, Maher J. Non-surgical interventions for late radiation cystitis in patients who have received radical radiotherapy to the pelvis. Cochrane Database Syst Rev 2002;2002:CD001773.

69. Alesawi AM, El-Hakim A, Zorn KC, et al. Radiationinduced hemorrhagic cystitis. Curr Opin Support Palliat Care 2014;8:235-40.

70. Mendenhall WM, Henderson RH, Costa JA, et al. Hemorrhagic radiation cystitis. Am J Clin Oncol 2015;38:331-6.

71. Capelli-Schellpfeffer M, Gerber GS. The use of hyperbaric oxygen in urology. J Urol 1999;162:647-54.

72. Pascoe C, Duncan C, Lamb BW, et al. Current management of radiation cystitis: a review and practical guide to clinical management. BJU Int 2019;123:585-94.

73. Al Hussein Al Awamlh B, Lee DJ, Nguyen DP, et al. Assessment of the quality-of-life and functional outcomes in patients undergoing cystectomy and urinary diversion for the management of radiation-induced refractory benign disease. Urology 2015;85:394-400.

74. Payne H, Adamson A, Bahl A, et al. Chemical- and radiation-induced haemorrhagic cystitis: Current treatments and challenges. BJU Int 2013;112:885-97.

75. Matta R, Chapple CR, Fisch M, et al. Pelvic Complications After Prostate Cancer Radiation Therapy and Their Management: An International Collaborative Narrative Review. Eur Urol 2019;75:464-76.

76. Choe KS, Jani AB, Liauw SL. External Beam Radiotherapy for Prostate Cancer Patients on Anticoagulation Therapy: How Significant is the Bleeding Toxicity? Int J Radiat Oncol Biol Phys 2010;76:755-60.

77. Goswami AK, Mahajan RK, Nath R, et al. How safe is $1 \%$ alum irrigation in controlling intractable vesical hemorrhage? J Urol 1993;149:264-7.

78. Choong SKS, Walkden M, Kirby R. The management of intractable haematuria. BJU Int 2000;86:951-9.

79. Mićić S, Genbacev O. Post-irradiation cystitis improved by instillation of early placental extract in saline. Eur Urol 1988;14:291-3.

80. Miura M, Sasagawa I, Kubota Y, et al. Effective hyperbaric oxygenation with prostaglandin E1 for radiation cystitis and colitis after pelvic radiotherapy. Int Urol Nephrol 1996;28:643-7.

81. Hemal AK, Vaidyanathan S, Sankaranarayanan A, et al. Control of massive vesical hemorrhage due to radiation cystitis with intravesical instillation of 15 (s) 15-methyl prostaglandin F2-alpha. Int J Clin Pharmacol Ther Toxicol 1988;26:477-8.

82. Hemal AK, Praveen BV, Sankaranarayanan A, et al. Control of persistent vesical bleeding due to radiation cystitis by intravesical application of 15 (S) 15-methyl prostaglandin F2-alpha. Indian J Cancer 1989;26:99-101.

83. Raghavaiah NV, Soloway MS. Anuria following silver nitrate irrigation for intractable bladder hemorrhage. J Urol 1977;118:681-2.

84. Montgomery BD, Boorjian SA, Ziegelmann MJ, et al. Intravesical silver nitrate for refractory hemorrhagic cystitis. Turk J Urol 2016;42:197-201.

85. Pool TL. Irradiation cystitis. J Am Med Assoc 1958;168:854-6.

86. Kumar AP, Wrenn EL, Jayalakshmamma B, et al. Silver nitrate irrigation to control bladder hemorrhage in children receiving cancer therapy. J Urol 1976;116:85-6.

87. Singh I, Laungani GB. Intravesical epsilon aminocaproic acid in management of intractable bladder hemorrhage. Urology 1992;40:227-9.

88. Shao Y, Lu GL, Shen ZJ. Comparison of intravesical 
hyaluronic acid instillation and hyperbaric oxygen in the treatment of radiation-induced hemorrhagic cystitis. BJU Int 2012;109:691-4.

89. Connolly SS, D'Arcy FT, Corcoran MO. Recombinant activated factor VII to control life-threatening haemorrhagic radiation cystitis. Ir J Med Sci 2010;179:431-3.

90. Geisler JP, Linnemeier GC, Manahan KJ. Recombinant factor VIIa to treat late radiation-induced hemorrhagic cystitis: A case report. J Reprod Med 2008;53:360-2.

91. Nascimento JC, Campelo MWS, Aragão IA, et al. Treatment of Severe Refractory Hematuria due to Radiation-Induced Hemorrhagic Cystitis with Dexamethasone. Case Rep Med 2017;2017:1560363.

92. Rajaganapathy BR, Janicki JJ, Levanovich P, et al. Intravesical Liposomal Tacrolimus Protects against Radiation Cystitis Induced by 3-Beam Targeted Bladder Radiation. J Urol 2015;194:578-84.

93. Dave CN, Chaus F, Chancellor MB, et al. Innovative use of intravesical tacrolimus for hemorrhagic radiation cystitis. Int Urol Nephrol 2015;47:1679-81.

94. Ostroff EB, Chenault OW. Alum irrigation for the control of massive bladder hemorrhage. J Urol 1982;128:929-30.

95. Arrizabalaga M, Extramina J, Parra JL, et al. Treatment of Massive Haematuria with Aluminous Salts. Br J Urol 1987;60:223-6.

96. Westerman ME, Boorjian SA, Linder BJ. Safety and efficacy of intravesical alum for intractable hemorrhagic cystitis: A contemporary evaluation. Int Braz J Urol 2016;42:1144-9.

97. Kavoussi LR, Gelstein LD, Andriole GL. Encephalopathy and an elevated serum aluminum level in a patient receiving intravesical alum irrigation for severe urinary hemorrhage. J Urol 1986;136:665-7.

98. Goel AK, Rao MS, Bhagwat AG, et al. Intravesical irrigation with alum for the control of massive bladder hemorrhage. J Urol 1985;133:956-7.

99. Kennedy C, Snell ME, Witherow RO. Use of alum to control intractable vesical haemorrhage. Br J Urol 1984;56:673-5.

100. Phelps KR, Naylor K. Encephalopathy after bladder irrigation with alum: case report and literature review. Am J Med Sci 1999;318:181-5.

101. Shah BC, Albert DJ. Intravesical instillation of formalin for the management of intractable hematuria. J Urol 1973;110:519-20.

102. Fair WR. Formalin in the treatment of massive bladder hemorrhage. Techniques, results, and complications.
Urology 1974;3:573-6.

103. Donahue LA, Frank IN. Intravesical formalin for hemorrhagic cystitis: analysis of therapy. J Urol 1989;141:809-12.

104.Ziegelmann MJ, Boorjian SA, Joyce DD, et al. Intravesical formalin for hemorrhagic cystitis: A contemporary cohort. Can Urol Assoc J 2017;11:E79-E82.

105. Dewan AK, Madan Mohan G, Ravi R. Intravesical formalin for hemorrhagic cystitis following irradiation of cancer of the cervix. Int J Gynaecol Obstet 1993;42:131-5.

106. Gottesman J, Ehrlich RM. Preventing vesicoureteral reflux during intravesical formalin instillation. Urology 1974;3:494-5.

107. Bright JF, Tosi SE, Crichlow RW, et al. Prevention of vesicoureteral reflux with Fogarty catheters during formalin therapy. J Urol 1977;118:950-2.

108. Lojanapiwat B, Sripralakrit S, Soonthornphan S, et al. Intravesicle formalin instillation with a modified technique for controlling haemorrhage secondary to radiation cystitis. Asian J Surg 2002;25:232-5.

109. Godec CJ, Gleich P. Intractable hematuria and formalin. J Urol 1983;130:688-91.

110. Vicente J, Rios G, Caffaratti J. Intravesical formalin for the treatment of massive hemorrhagic cystitis: Retrospective review of 25 cases. Eur Urol 1990;18:204-6.

111.Lowe BA, Stamey TA. Endoscopic Topical Placement of Formalin Soaked Pledgets to Control Localized Hemorrhage Due to Radiation Cystitis. J Urol 1997;158:528-9.

112. Fall M, Pettersson S. Ureteral complications after intravesical formalin instillation. J Urol 1979;122:160-2.

113. Browne C, Davis NF, Mac Craith E, et al. A Narrative Review on the Pathophysiology and Management for Radiation Cystitis. Adv Urol 2015;2015:346812.

114.Hampson SJ, Woodhouse CRJ. Sodium pentosanpolysulphate in the management of haemorrhagic cystitis: Experience with 14 patients. Eur Urol 1994;25:40-2.

115. Sandhu SS, Goldstraw M, Woodhouse CRJ. The management of haemorrhagic cystitis with sodium pentosan polysulphate. BJU Int 2004;94:845-7.

116. Parsons CL. Successful management of radiation cystitis with sodium pentosanpolysulfate. J Urol 1986;136:813-4.

117. Veerasarn V, Khorprasert C, Lorvidhaya V, et al. Reduced recurrence of late hemorrhagic radiation cystitis by WF10 therapy in cervical cancer patients: A multicenter, randomized, two-arm, open-label trial. Radiother Oncol 2004;73:179-85. 
118. Veerasarn V, Boonnuch W, Kakanaporn C. A phase II study to evaluate WF10 in patients with late hemorrhagic radiation cystitis and proctitis. Gynecol Oncol 2006;100:179-84.

119. Miller J, Burfield GD, Moretti KL. Oral conjugated estrogen therapy for treatment of hemorrhagic cystitis. J Urol 1994;151:1348-50.

120. Thompson A, Adamson A, Bahl A, et al. Guidelines for the diagnosis, prevention and management of chemical- and radiation-induced cystitis. J Clin Urol 2014;7:25-35.

121. Weiss JP, Mattei DM, Neville EC, et al. Primary treatment of radiation-induced hemorrhagic cystitis with hyperbaric oxygen: 10-Year experience. J Urol 1994;151:1514-7.

122. Chong KT, Hampson NB, Corman JM. Early hyperbaric oxygen therapy improves outcome for radiation-induced hemorrhagic cystitis. Urology 2005;65:649-53.

123. Pasquier D, Hoelscher T, Schmutz J, et al. Hyperbaric oxygen therapy in the treatment of radio-induced lesions in normal tissues: A literature review. Radiother Oncol 2004;72:1-13.

124. Ribeiro de Oliveira TM, Carmelo Romão AJ, Gamito Guerreiro FM, et al. Hyperbaric oxygen therapy for refractory radiation-induced hemorrhagic cystitis. Int J Urol 2015;22:962-6.

125.Yoshida T, Kawashima A, Ujike T, et al. Hyperbaric oxygen therapy for radiation-induced hemorrhagic cystitis. Int J Urol 2008;15:639-41.

126. Corman JM, McClure D, Pritchett R, et al. Treatment of radiation induced hemorrhagic cystitis with hyperbaric oxygen. J Urol 2003;169:2200-2.

127.Dellis A, Deliveliotis C, Kalentzos V, et al. Is there a role for hyberbaric oxygen as primary treatment for grade IV radiation-induced haemorrhagic cystitis? A prospective pilot-feasibility study and review of literature. Int Braz J Urol 2014;40:296-305.

128. Del Pizzo JJ, Chew BH, Jacobs SC, et al. Treatment of radiation induced hemorrhagic cystitis with hyperbaric oxygen: long-term followup. J Urol 1998;160:731-3.

129. Degener S, Pohle A, Strelow H, et al. Long-term experience of hyperbaric oxygen therapy for refractory radio- or chemotherapy-induced haemorrhagic cystitis Endourology and technology. BMC Urol 2015;15:38.

130.Nakada T, Nakada H, Yoshida Y, et al. Hyperbaric oxygen therapy for radiation cystitis in patients with prostate cancer: a long-term follow-up study. Urol Int 2012;89:208-14.

131.Polom W, Klejnotowska A, Matuszewski M, et al. Hyperbaric oxygen therapy (HBOT) in case of hemorrhagic cystitis after radiotherapy. Cent European J Urol 2012;65:200-3.

132. Oliai C, Fisher B, Jani A, et al. Hyperbaric oxygen therapy for radiation-induced cystitis and proctitis. Int J Radiat Oncol Biol Phys 2012;84:733-40.

133. Dellis A, Papatsoris A, Kalentzos V, et al. Hyberbaric oxygen as sole treatment for severe radiation - induced haemorrhagic cystitis. Int Braz J Urol 2017;43:489-95.

134. Mougin J, Souday V, Martin F, et al. Evaluation of Hyperbaric Oxygen Therapy in the Treatment of Radiation-induced Hemorrhagic Cystitis. Urology 2016;94:42-6.

135. Shilo Y, Efrati S, Simon Z, et al. Hyperbaric oxygen therapy for hemorrhagic radiation cystitis. Isr Med Assoc J $2013 ; 15: 75-8$.

136. Oscarsson N, Arnell P, Lodding P, et al. Hyperbaric oxygen treatment in radiation-induced cystitis and proctitis: A prospective cohort study on patient-perceived quality of recovery. Int J Radiat Oncol Biol Phys 2013;87:670-5.

137. Ravi R. Endoscopic neodymium: YAG laser treatment of radiation-induced hemorrhagic cystitis. Lasers Surg Med 1994; $14: 83-7$.

138.Zhu J, Xue B, Shan Y, et al. Transurethral coagulation for radiation-induced hemorrhagic cystitis using greenlightTM potassium-titanyl-phosphate laser. Photomed Laser Surg 2013;31:78-81.

139. Suzuki S, Chino A, Fukui I, et al. Successful use of endoscopic argon plasma coagulation for hemorrhagic radiation cystitis: A case report. Jpn J Clin Oncol 2014;44:692-5.

140.Martinez DR, Ercole CE, Lopez JG, et al. A novel approach for the treatment of radiation-induced hemorrhagic cystitis with the GreenLightTM XPS laser. Int Braz J Urol 2015;41:584-7.

141. Wines MP, Lynch WD. A new minimally invasive technique for treating radiation cystitis: the argon-beam coagulator. BJU Int 2006;98:610-2.

142. Talab SS, McDougal WS, Wu CL, et al. Mucosa-sparing, KTP laser coagulation of submucosal telangiectatic vessels in patients with radiation-induced cystitis: A novel approach. Urology 2014;84:478-83.

143. Holstein P, Jacobsen K, Pedersen JF, et al. Intravesical hydrostatic pressure treatment: new method for control of bleeding from the bladder mucosa. J Urol 1973;109:234-6.

144.Mufti GR, Virdi JS, Singhi M. Reappraisal of hydrostatic pressure treatment for intractable postradiotherapy vesical hemorrhage. Urology 1990;35:9-11 
145. Chuang YC, Kim DK, Chiang PH, et al. Bladder botulinum toxin A injection can benefit patients with radiation and chemical cystitis. BJU Int 2008;102:704-6.

146. De Berardinis E, Vicini P, Salvatori F, et al. Superselective embolization of bladder arteries in the treatment of intractable bladder haemorrhage. Int J Urol 2005;12:503-5.

147.Delgal A, Cercueil JP, Koutlidis N, et al. Outcome of Transcatheter Arterial Embolization for Bladder and Prostate Hemorrhage. J Urol 2010;183:1947-53.

148. Korkmaz M, Åžanal B, Aras B, et al. The short-and longterm effectiveness of transcatheter arterial embolization in patients with intractable hematuria. Diagn Interv Imaging 2016;97:197-201.

149.Palandri F, Bonifazi F, Rossi C, et al. Successful treatment of severe hemorrhagic cystitis with selective vesical artery embolization. Bone Marrow Transplant 2005;35:529-30.

150.Loffroy R, Pottecher P, Cherblanc V, et al. Current role of transcatheter arterial embolization for bladder and prostate hemorrhage. Diagn Interv Imaging 2014;95:1027-34.

151.McIvor J, Williams G, Greswick Southcott RD. Control of severe vesical haemorrhage by therapeutic embolisation. Clin Radiol 1982;33:561-7.

152. Sneiders A, Pryor JL. Percutaneous nephrostomy drainage in the treatment of severe hemorrhagic cystitis. J Urol 1993;150:966-7.

153. Ravi R, Dewan AK, Pandey KK. Transverse colon conduit urinary diversion in patients treated with very high dose pelvic irradiation. Br J Urol 1994;73:51-4.

154.Pomer S, Karcher G, Simon W. Cutaneous Ureterostomy as Last Resort Treatment of Intractable Haemorrhagic Cystitis Following Radiation. Br J Urol 1983;55:392-4.

155.Zagoria RJ, Hodge RG, Dyer RB, et al. Percutaneous nephrostomy for treatment of intractable hemorrhagic cystitis. J Urol 1993;149:1449-51.

156. Fazili T, Bhat TR, Masood S, et al. Fate of the Leftover Bladder After Supravesical Urinary Diversion for Benign Disease. J Urol 2006;176:620-1.

157. Adeyoju AB, Lynch TH, Thornhill JA. The defunctionalized bladder. Int Urogynecol J Pelvic Floor Dysfunct 1998;9:48-51.

158. Adeyoju AB, Thornhill J, Lynch T, et al. The fate of the defunctioned bladder following supravesical urinary diversion. Br J Urol 1996;78:80-3.

159. Sack BS, Langenstroer P, Guralnick ML, et al. Cystectomy and urinary diversion for the management of a devastated lower urinary tract following prostatic cryotherapy and/or radiotherapy. WMJ 2016;115:70-3.

160. Linder BJ, Tarrell RF, Boorjian SA. Cystectomy for refractory hemorrhagic cystitis: Contemporary etiology, presentation and outcomes. J Urol 2014;192:1687-92.

161. Kocot A, Riedmiller H. Fisteln des Urogenitaltraktes nach Strahlentherapie. Urologe A 2017;56:329-35.

162.Angioli R, Penalver M, Muzii L, et al. Guidelines of how to manage vesicovaginal fistula. Crit Rev Oncol Hematol 2003;48:295-304.

163.Zoubek J, McGuire EJ, Noll F, et al. The late occurrence of urinary tract damage in patients successfully treated by radiotherapy for cervical carcinoma. J Urol 1989;141:1347-9.

164. Viennas LK. Repair of radiation-induced vesicovaginal fistula with a rectus abdominis myocutaneous flap. Plast Reconstr Surg 1995;96:1435-7.

165. Chrouser KL, Leibovich BC, Sweat SD, et al. Urinary fistulas following external radiation or permanent brachytherapy for the treatment of prostate cancer. J Urol 2005;173:1953-7.

166. Stone NN, Stock RG. Complications following permanent prostate brachytherapy. Eur Urol 2002;41:427-33.

167.Hennessey DB, Bolton E, Thomas AZ, et al. Vesicocutaneous fistula following adjuvant radiotherapy for prostate cancer. BMJ Case Rep 2013;2013:bcr2013008986.

168. Keady C, Hechtl D, Joyce M. When the bowel meets the bladder: Optimal management of colorectal pathology with urological involvement. World J Gastrointest Surg 2020;12:208-25.

169. Ramírez-Martín D, Jara-Rascón J, Renedo-Villar T, et al. Rectourethral Fistula Management. Curr Urol Rep 2016;17:22.

170. Golabek T, Szymanska A, Szopinski T, et al. Enterovesical fistulae: Aetiology, imaging, and management. Gastroenterol Res Pract 2013;2013:617967.

171. Dean RJ, Lytton B. Urologic complications of pelvic irradiation. J Urol 1978;119:64-7.

172.Pourquier H, Delard R, Achille E, et al. A quantified approach to the analysis and prevention of urinary complications in radiotherapeutic treatment of cancer of the cervix. Int J Radiat Oncol Biol Phys 1987;13:1025-33.

173.McBeath RB, Schiff M, Allen V, et al. A 12-year experience with enterovesical fistulas. Urology 1994;44:661-5.

174. Mahlknecht A, Bizzotto L, Gamper C, et al. A rare complication of ureteral stenting: Case report of a ureteroarterial fistula and revision of the literature. Arch Ital Urol Androl 2018;90:215-7.

175. Bergqvist D, Pärsson H, Sherif A. Arterio-ureteral 
fistula - A systematic review. Eur J Vasc Endovasc Surg 2001;22:191-6.

176. Kim SW, Lee JN, Kim HT, et al. Management of a patient with vesicocutaneous fistula presenting 13 years after radiotherapy performed for cervical cancer. Turk J Urol 2018;44:185-8.

177. Kaufman DA, Browne BM, Zinman LN, et al. Management of Radiation Anterior Prostato-symphyseal Fistulas with Interposition Rectus Abdominis Muscle Flap. Urology 2016;92:122-6.

178.El-Azab AS, Abolella HA, Farouk M. Update on vesicovaginal fistula: A systematic review. Arab J Urol 2019;17:61-8.

179. Kavanagh D, Neary P, Dodd JD, et al. Diagnosis and treatment of enterovesical fistulae. Colorectal Dis 2005;7:286-91.

180. Daniels IR, Bekdash B, Scott HJ, et al. Diagnostic lessons learnt from a series of enterovesical fistulae. Colorectal Dis 2002;4:459-62.

181.Larsen A, Johansen TEB, Solheim BM, et al. Diagnosis and treatment of enterovesical fistula. Eur Urol 1996;29:318-21.

182. Nyam DCNK, Pemberton JH. Management of iatrogenic rectourethral fistula. Dis Colon Rectum 1999;42:994-7.

183. Spahn M, Vergho D, Riedmiller H. Iatrogenic rectourethral fistula: Perineal repair and buccal mucosa interposition. BJU Int 2009; 103:242-6.

184. Mundy AR, Andrich DE. Urorectal fistulae following the treatment of prostate cancer. BJU Int 2011;107:1298-303.

185.Lau KO, Cheng C. A case report - Delayed vesicocutaneous fistula after radiation therapy for advanced vulvar cancer. Ann Acad Med Singapore 1998;27:705-6.

186. Eilber KS, Kavaler E, Rodríguez LV, et al. Ten-year experience with transvaginal vesicovaginal fistula repair using tissue interposition. J Urol 2003;169:1033-6.

187.Evans DH, Madjar S, Politano VA, et al. Interposition flaps in transabdominal vesicovaginal fistula repairs: are they really necessary? Urology 2001;57:670-4.

188. Shoukry MS, Hassouna ME, El-Salmy S, et al. Vaginal flap re-enforcement of vesico-vaginal fistula repair. Int Urogynecol J 2010;21:829-33.

189. Collins CG, Pent D, Jones FB. Results of early repair of vesicovaginal fistula with preliminary cortisone treatment. Am J Obstet Gynecol 1960;80:1005-12.

190. Gil-Vernet JM, Gil-Vernet A, Campos JA. New surgical approach for treatment of complex vesicovaginal fistula. J Urol 1989;141:513-6.

191. Gómez-Iturriaga Piña A, Crook J, Borg J, et al. Median
5 Year Follow-up of 125Iodine Brachytherapy as Monotherapy in Men Aged $\leq 55$ Years With Favorable Prostate Cancer. Urology 2010;75:1412-6.

192.Lane BR, Stein DE, Remzi FH, et al. Management of radiotherapy induced rectourethral fistula. J Urol 2006;175:1382-7.

193.Vanni AJ, Buckley JC, Zinman LN. Management of surgical and radiation induced rectourethral fistulas with an interposition muscle flap and selective buccal mucosal onlay graft. J Urol 2010;184:2400-4.

194. Sotelo R, Mirandolino M, Trujillo G, et al. Laparoscopic Repair of Rectourethral Fistulas After Prostate Surgery. Urology 2007;70:515-8.

195. Ghoniem G, Elmissiry M, Weiss E, et al. Transperineal Repair of Complex Rectourethral Fistula Using Gracilis Muscle Flap Interposition-Can Urinary and Bowel Functions be Preserved? J Urol 2008;179:1882-6.

196. Moreira SG, Seigne JD, Ordorica RC, et al. Devastating complications after brachytherapy in the treatment of prostate adenocarcinoma. BJU Int 2004;93:31-5.

197.Zinman L. The management of the complex recto-urethral fistula. BJU Int 2004;94:1212-3.

198.Zmora O, Potenti FM, Wexner SD, et al. Gracilis Muscle Transposition for Iatrogenic Rectourethral Fistula. Ann Surg 2003;237:483-7.

199. Maier U, Ehrenböck PM, Hofbauer J. Late urological complications and malignancies after curative radiotherapy for gynecological carcinomas: A retrospective analysis of 10,709 patients. J Urol 1997;158:814-7.

200. Fokdal L, Tanderup K, Pötter R, et al. Risk Factors for Ureteral Stricture After Radiochemotherapy Including Image Guided Adaptive Brachytherapy in Cervical Cancer: Results From the EMBRACE Studies. Int J Radiat Oncol Biol Phys 2019;103:887-94.

201.Goodman M, Dalton JR. Ureteral strictures following radiotherapy: Incidence, etiology and treatment guidelines. J Urol 1982;128:21-4.

202.Jarosek SL, Virnig BA, Chu H, et al. Propensityweighted long-term risk of urinary adverse events after prostate cancer surgery, radiation, or both. Eur Urol 2015;67:273-80.

203.Perez CA, Lee HK, Georgiou A, et al. Technical factors affecting morbidity in definitive irradiation for localized carcinoma of the prostate. Int J Radiat Oncol Biol Phys 1994;28:811-9.

204. Miller RC, Haddock MG, Petersen IA, et al. Intraoperative electron-beam radiotherapy and ureteral obstruction. Int $\mathbf{J}$ Radiat Oncol Biol Phys 2006;64:792-8. 
205. Reus C, Brehmer M. Minimally invasive management of ureteral strictures: a 5-year retrospective study. World J Urol 2019;37:1733-8.

206. Siegel J, Simhan J, Tausch TJ, et al. Ureteral strictures and reconstruction in the cancer survivor. Curr Opin Urol 2014;24:421-6.

207. Muram D, Oxorn H, Curry RH, et al. Postradiation ureteral obstruction: A reappraisal. Am J Obstet Gynecol 1981;139:289-93.

208. Taylor PM, Johnson RJ, Eddleston B, et al. Radiological changes in the gastrointestinal and genitourinary tract following radiotherapy for carcinoma of the cervix. Clin Radiol 1990;41:165-9.

209. Riedmiller H, Becht E, Hertle L, et al. Psoas-hitch ureteroneocystostomy: Experience with 181 cases. Eur Urol 1984;10:145-50.

210. Orchard J, Tward JD, Lenherr S, et al. Surgical Management of Ureteral Strictures Arising From Radiotherapy for Prostate Cancer. Urol Case Rep 2016;6:47-9.

211. Iwaszko MR, Krambeck AE, Chow GK, et al. Transureteroureterostomy Revisited: Long-Term Surgical Outcomes. J Urol 2010;183:1055-9.

212.Armatys SA, Mellon MJ, Beck SDW, et al. Use of Ileum as Ureteral Replacement in Urological Reconstruction. J Urol 2009; 181:177-81.

213.Lazica DA, Ubrig B, Brandt AS, et al. Ureteral substitution with reconfigured colon: Long-term followup. J Urol 2012;187:542-8.

214. Ubrig B, Waldner M, Roth S. Reconstruction of ureter with transverse retubularized colon segments. J Urol 2001;166:973-6.

215.Kranz J, Maurer G, Maurer U, et al. Harnröhrenstrikturrate nach Bestrahlung eines Prostatakarzinoms. Urologe A 2017;56:336-41.

216. Shin JY, Yoon SM, Choi HJ, et al. A case of postradiotherapy urethral stricture with spontaneous bladder rupture, mimicking obstructive uropathy due to cancer metastasis. Electrolyte Blood Press 2014;12:26-9.

217. Awad MA, Gaither TW, Osterberg EC, et al. Prostate cancer radiation and urethral strictures: A systematic review and meta-analysis. Prostate Cancer Prostatic Dis 2018;21:168-74.

218. Elliott SP, Meng MV, Elkin EP, et al. Incidence of Urethral Stricture After Primary Treatment for Prostate Cancer: Data From CaPSURE. J Urol 2007;178:529-34.

219. Moltzahn F, Pra AD, Furrer M, et al. Urethral strictures after radiation therapy for prostate cancer. Investig Clin
Urol 2016;57:309-15.

220.Merrick GS, Butler WM, Wallner KE, et al. Risk factors for the development of prostate brachytherapy related urethral strictures. J Urol 2006;175:1376-80.

221. Sullivan L, Williams SG, Tai KH, et al. Urethral stricture following high dose rate brachytherapy for prostate cancer. Radiother Oncol 2009;91:232-6.

222. Glass AS, McAninch JW, Zaid UB, et al. Urethroplasty after radiation therapy for prostate cancer. Urology 2012;79:1402-5.

223. Meeks JJ, Brandes SB, Morey AF, et al. Urethroplasty for radiotherapy induced bulbomembranous strictures: A multi-institutional experience. J Urol 2011;185:1761-5.

224. Ahyai SA, Schmid M, Kuhl M, et al. Outcomes of Ventral Onlay Buccal Mucosa Graft Urethroplasty in Patients after Radiotherapy. J Urol 2015;194:441-6.

225.Hindson BR, Millar JL, Matheson B. Urethral strictures following high-dose-rate brachytherapy for prostate cancer: Analysis of risk factors. Brachytherapy 2013;12:50-5.

226. Mohammed N, Kestin L, Ghilezan M, et al. Comparison of acute and late toxicities for three modern high-dose radiation treatment techniques for localized prostate cancer. Int J Radiat Oncol Biol Phys 2012;82:204-12.

227. Seymore CH, El-Mahdi AM, Schellhammer PF. The effect of prior transurethral resection of the prostate on post radiation urethral strictures and bladder neck contractures. Int J Radiat Oncol Biol Phys 1986;12:1597-600.

228. Ishiyama H, Hirayama T, Jhaveri P, et al. Is there an increase in genitourinary toxicity in patients treated with transurethral resection of the prostate and radiotherapy? A systematic review. Am J Clin Oncol 2014;37:297-304.

229. Tibbs MK. Wound healing following radiation therapy: A review. Radiother Oncol 1997;42:99-106.

230. Hofer MD, Zhao LC, Morey AF, et al. Outcomes after urethroplasty for radiotherapy induced bulbomembranous urethral stricture disease. J Urol 2014;191:1307-12.

231.Hampson LA, McAninch JW, Breyer BN. Male urethral strictures and their management. Nat Rev Urol 2014;11:43-50.

232. Mundy AR, Andrich DE. Urethral strictures. BJU Int 2011;107:6-26.

233. Nicholson HL, Al-Hakeem Y, Maldonado JJ, et al. Management of bladder neck stenosis and urethral stricture and stenosis following treatment for prostate cancer. Transl Androl Urol 2017;6:S92-S102.

234. Herschorn S, Elliott S, Coburn M, et al. SIU/ICUD consultation on urethral strictures: Posterior urethral 
stenosis after treatment of prostate cancer. Urology 2014;83:S59-70.

235.Liberman D, Jarosek S, Virnig BA, et al. The patient burden of bladder outlet obstruction after prostate cancer treatment. J Urol 2016;195:1459-63.

236. Hudak SJ, Atkinson TH, Morey AF. Repeat transurethral manipulation of bulbar urethral strictures is associated with increased stricture complexity and prolonged disease duration. J Urol 2012;187:1691-5.

237. Milose JC, Gonzalez CM. Urethroplasty in radiationinduced strictures. Curr Opin Urol 2015;25:336-40.

238. Chi AC, Han J, Gonzalez CM. Urethral strictures and the cancer survivor. Curr Opin Urol 2014;24:415-20.

239. Khourdaji I, Parke J, Chennamsetty A, et al. Treatment of Urethral Strictures from Irradiation and Other Nonsurgical Forms of Pelvic Cancer Treatment. Adv Urol 2015;2015:476390.

240.Wessells H, Angermeier KW, Elliott S, et al. Male Urethral Stricture: American Urological Association Guideline. J Urol 2017;197:182-90.

241. Rourke K, Kinnaird A, Zorn J. Observations and outcomes of urethroplasty for bulbomembranous stenosis after radiation therapy for prostate cancer. World J Urol 2016;34:377-82.

242. Elliott SP, McAninch JW, Chi T, et al. Management of Severe Urethral Complications of Prostate Cancer Therapy. J Urol 2006;176:2508-13.

243. Fuchs JS, Hofer MD, Sheth KR, et al. Improving Outcomes of Bulbomembranous Urethroplasty for Radiation-induced Urethral Strictures in Post-Urolume Era. Urology 2017;99:240-5.

244. Palmer DA, Buckley JC, Zinman LN, et al. Urethroplasty for high risk, long segment urethral strictures with ventral buccal mucosa graft and gracilis muscle flap. J Urol 2015;193:902-5.

245.Palmer RM. Perioperative care of the elderly patient: An update. Cleve Clin J Med 2009;76:S16-21.

246. Faris SF, Milam DF, Dmochowski RR, et al. Urinary diversions after radiation for prostate cancer: Indications and treatment. Urology 2014;84:702-6.

247. Suit H, Goldberg S, Niemierko A, et al. Secondary Carcinogenesis in Patients Treated with Radiation: A Review of Data on Radiation-Induced Cancers in Human, Non-human Primate, Canine and Rodent Subjects. Radiat Res 2007;167:12-42.

248.Li CI, Nishi N, McDougall JA, et al. Relationship between radiation exposure and risk of second primary cancers among atomic bomb survivors. Cancer Res
2010;70:7187-98.

249. Little JB. Radiation carcinogenesis. Carcinogenesis 2000;21:397-404.

250.Janulionis E, Samerdokiene V, Valuckas KP, et al. Second primary malignancies after high-dose-rate 60 Co photon or 252 Cf neutron brachytherapy in conjunction with external-beam radiotherapy for endometrial cancer. Brachytherapy 2018;17:768-74.

251.Preston DL, Ron E, Tokuoka S, et al. Solid Cancer Incidence in Atomic Bomb Survivors: 1958-1998. Radiat Res 2007;168:1-64.

252. Cardis E, Howe G, Ron E, et al. Cancer consequences of the Chernobyl accident: 20 Years on. J Radiol Prot 2006;26:127-40.

253. Chaturvedi AK, Engels EA, Gilbert ES, et al. Second cancers among 104,760 survivors of cervical cancer: evaluation of long-term risk. J Natl Cancer Inst 2007;99:1634-43.

254. Kendal WS, Nicholas G. A population-based analysis of second primary cancers after irradiation for rectal cancer. Am J Clin Oncol 2007;30:333-9.

255. Rombouts AJM, Hugen N, Elferink MAG, et al. Incidence of second tumors after treatment with or without radiation for rectal cancer. Ann Oncol 2017;28:535-40.

256. Wallis CJD, Mahar AL, Choo R, et al. Second malignancies after radiotherapy for prostate cancer: Systematic review and meta-analysis. BMJ 2016;352:i851.

257. Murray L, Henry A, Hoskin P, et al. Second primary cancers after radiation for prostate cancer: A systematic review of the clinical data and impact of treatment technique. Radiother Oncol 2014;110:213-28.

258. Murray L, Henry A, Hoskin P, et al. Second primary cancers after radiation for prostate cancer: A review of data from planning studies. Radiat Oncol 2013;8:172.

259.Murray LJ, Thompson CM, Lilley J, et al. Radiationinduced second primary cancer risks from modern external beam radiotherapy for early prostate cancer: Impact of stereotactic ablative radiotherapy (SABR), volumetric modulated arc therapy (VMAT) and flattening filter free (FFF) radiotherapy. Phys Med Biol 2015;60:1237-57.

260.Abdel-Wahab M, Reis IM, Wu J, et al. Second Primary Cancer Risk of Radiation Therapy After Radical Prostatectomy for Prostate Cancer: An Analysis of SEER Data. Urology 2009;74:866-71.

261. Moon K, Stukenborg GJ, Keim J, et al. Cancer incidence after localized therapy for prostate cancer. Cancer 2006;107:991-8.

262. Suriano F, Altobelli E, Sergi F, et al. Bladder cancer after 
radiotherapy for prostate cancer. Rev Urol 2013;15:108-12.

263. Berrington de Gonzalez A, Wong J, Kleinerman R, et al. Risk of second cancers according to radiation therapy technique and modality in prostate cancer survivors. Int J Radiat Oncol Biol Phys 2015;91:295-302.

264. Singh AK, Mashtare TL, McCloskey SA, et al. Increasing age and treatment modality are predictors for subsequent diagnosis of bladder cancer following prostate cancer diagnosis. Int J Radiat Oncol Biol Phys 2010;78:1086-94.

265. Boorjian S, Cowan JE, Konety BR, et al. Bladder Cancer Incidence and Risk Factors in Men With Prostate Cancer: Results From Cancer of the Prostate Strategic Urologic Research Endeavor. J Urol 2007;177:883-7.

266. Martling A, Smedby KE, Birgisson H, et al. Risk of second primary cancer in patients treated with radiotherapy for rectal cancer. Br J Surg 2017;104:278-87.

267. Lee YC, Hsieh CC, Li CY, et al. Secondary Cancers After Radiation Therapy for Primary Prostate or Rectal Cancer. World J Surg 2016;40:895-905.

268. Hegemann NS, Schlesinger-Raab A, Ganswindt U, et al. Risk of second cancer following radiotherapy for prostate cancer: A population-based analysis. Radiat Oncol 2017;12:2.

269.Zelefsky MJ, Pei X, Teslova T, et al. Secondary cancers after intensity-modulated radiotherapy, brachytherapy

Cite this article as: Chorbińska J, Krajewski W, Zdrojowy R. Urological complications after radiation therapy-nothing ventured, nothing gained: a Narrative Review. Transl Cancer Res 2021;10(2):1096-1118. doi: 10.21037/tcr-20-2589 and radical prostatectomy for the treatment of prostate cancer: Incidence and cause-specific survival outcomes according to the initial treatment intervention. BJU Int 2012;110:1696-701.

270.Huang J, Kestin LL, Ye H, et al. Analysis of second malignancies after modern radiotherapy versus prostatectomy for localized prostate cancer. Radiother Oncol 2011;98:81-6.

271.Kendal WS, Eapen L, MacRae R, et al. Prostatic irradiation is not associated with any measurable increase in the risk of subsequent rectal cancer. Int J Radiat Oncol Biol Phys 2006;65:661-8.

272.Hoffman KE, Hong TS, Zietman AL, et al. External beam radiation treatment for rectal cancer is associated with a decrease in subsequent prostate cancer diagnosis. Cancer 2008;112:943-9.

273. Huo D, Hetzel JT, Roy H, et al. Association of colorectal cancer and prostate cancer and impact of radiation therapy. Cancer Epidemiol Biomarkers Prev 2009;18:1979-85.

274. Buchli C, Martling A, Arver S, et al. Testicular function after radiotherapy for rectal cancer-a review. J Sex Med 2011;8:3220-6.

275. Buchli C, Al Abani M, Ahlberg M, et al. Assessment of testicular dose during preoperative radiotherapy for rectal cancer. Acta Oncol 2016;55:496-501. 